\begin{tabular}{|l|l|}
\hline 2. To: (Receiving organization) & 3. Fron: Coriginating Organization) \\
Distribution & Process Engineering \\
\hline 5. Proj./Prog./Dept./Div.: & 6. Design Authority/ Design Agent/Cog. \\
SNF Project & J. A. A. Swenson \\
\hline
\end{tabular}

8. Originator Remarks;

Distribution of document for approval and release.

11. Receiver Remarks: 11A. Design Baseline Document? [] Yes $[X]$ No
4. Related EDT No.:

$\mathrm{N} / \mathrm{A}$

7. Purchase order No.:

N/A

9. Equip./Component No.:

$\mathrm{N} / \mathrm{A}$

10. Systen/Bldg./Facility:

$N / A$

12. Major Assm. Dwg. No.:

$$
N / A
$$

13. Permit/Permit Application No.: $N / A$

14. Required Response Date:

September 8, 1997

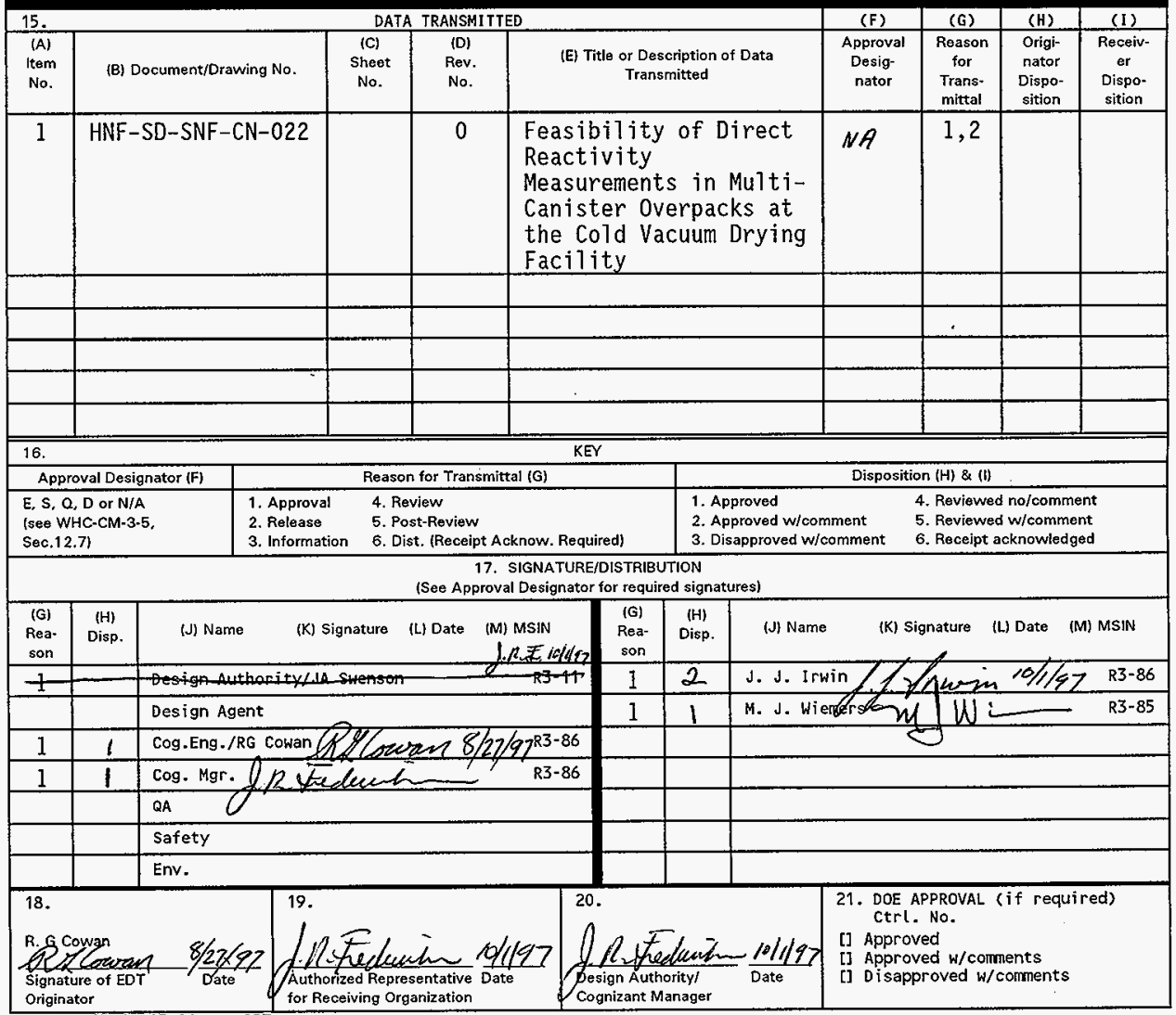




\section{Feasibility of Direct Reactivity Measurement in Multi-Canister Overpacks at the Cold Vacuum Drying Facility}

\section{R. G. Cowan}

DE\&S Hanford, INC., Richland, WA 99352

U.S. Department of Energy Contract DE-AC06-96RL13200

$\begin{array}{lll}\text { EDT/ECN: } & 616163 & \text { UC: } 510 \\ \text { Org Code: } & 2 T 710 & \text { Charge Code: LB05I } \\ \text { B\&R Code: } & \text { EW7040000 } & \text { Totaf Pages: } 57\end{array}$

Key Words: Spent Nuclear Fuel, Uranium Metal, Uranium - Water Reaction, Cold Vacuum Drying Faci]ity, MCO

Abstract: A proposed method for measuring the chemical reaction rate (power) of breached $\mathrm{N}$-Reactor fuel elements with water in an Multicanister overpack (MCO) based on hydrogen release rate is evaluated. The reaction rate is measured at $50{ }^{\circ} \mathrm{C}$ in an oxygen free water by applying a vacuum to boil the water and adding a low, measured flow of helium. The ratio of helium to hydrogen is used to infer the reaction rate. A test duration of less than 8 hours was found to provide sufficient accuracy for confidence in the measurement results. A more rigorous treatment of system measurement accuracy, which may yield shorter test durations, should be performed if this reactivity measurement is to be employed.

TRADEMARK DISCLAIMER. Reference herein to any specific comercial product, process, or service by trade name, tradernark, manufacturer, or otherwise, does not necessarily constitute or imply its endorsement, recommendation, or favoring by the United States Government or any agency thereof or its contractors or subcontractors.

Printed in the United States of America. To obtain copies of this document, contact: Document Control Services, P.0. Box 950, Mailstop H6-08, Richland WA 99352, Phone (509) 372-2420; Fax (509) 376-4989.
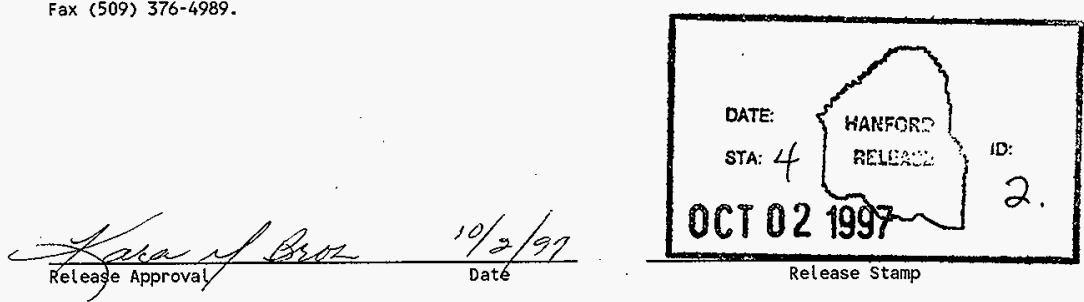
FAUSKE \& ASSOCIATES, INC.

CALCULATION NOTE COVER SHEET

SECTION TO BE COMPLETED BY AUTHOR(S):

Page $\angle$ of 48

Calc-Note Number

FAI/97-32

Revision Number 0

Title Feasibility of Direct Reactivity Measurement in MCOs at the Cold Vacuum Drying Facility (CVDF)

Project

Hanford SNFP

Shop Order

WE133-9

Purpose: Assess the feasibility of quantifying the reactive uranium metal area in an MCO upon its delivery to the CVDF for processing.

Results Summary: Two techniques for conducting a direct reactivity measurement were considered, i.e., helium purge and MCO pressurization and both were judged to be feasible. The hydrogen purge method was judged to be the best choice due to its expected capability of faster reactivity measurements.

Author(s):

Name (Print or Type)

Signature

Completion

Date

R. J. Hammersley

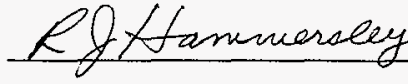

April 9. 1997

\section{SECTION TO BE COMPLETED BY VERIFIER(S):}

\begin{tabular}{|lc|}
\hline $\begin{array}{l}\text { Verifier(s): } \\
\text { Name (Print or Type) }\end{array}$ & $\begin{array}{c}\text { Completion } \\
\text { Date }\end{array}$ \\
\hline Indg. P1ya & 4.23 .97 \\
\hline Verification Method:
\end{tabular}

\section{SECTION TO BE COMPLETED BY MANAGER:}

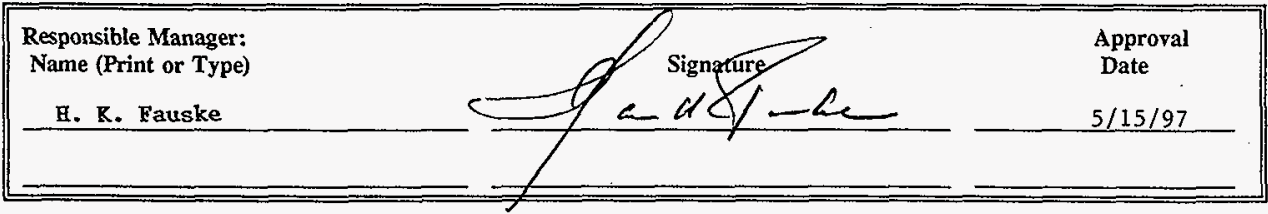




\section{Prepared by}

Fauske \& Associates, Inc. 16W070 West 83rd Street

Burr Ridge, Illinois 60521

Phone: 630-323-8750

Fax: 630-986-5481

March, 1997 


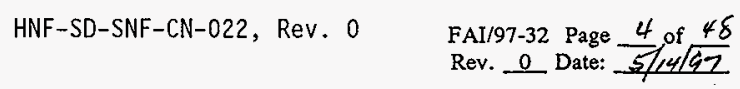

TABLE OF CONTENTS

Page

CALCULATION COVER SHEET $\ldots \ldots \ldots \ldots \ldots \ldots \ldots \ldots \ldots \ldots \ldots \ldots$

CALCULATION METHODOLOGY CHECKLIST . . . . . . . . . . . . . . ii

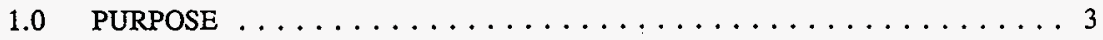

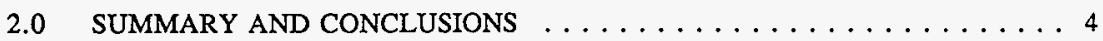

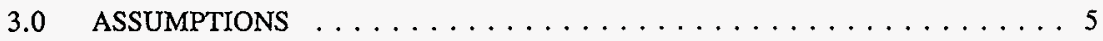

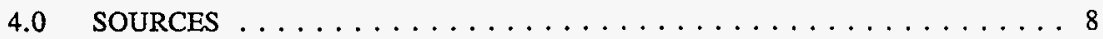

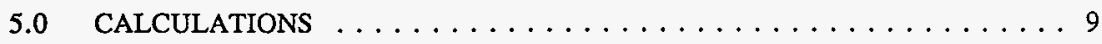

5.1 Order of Magnitude Assessment of Test Parameter Uncertainties . . . . . . 9

5.1 .1 Thermal Effects ..................... 11

5.1 .2 Gas Soluility and Adsorption/Absorption Effects ......... 12

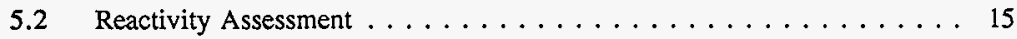

5.3 Measurement Procedure Considerations $\ldots \ldots \ldots \ldots$

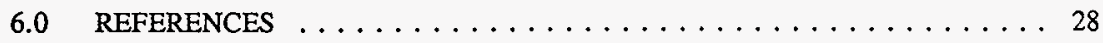

APPENDIX A $\quad$ Closed MCO Reactivity Measurement . . . . . . . . . . A-1 


\subsection{PURPOSE}

The purpose of this calculation is to assess the feasibility of an integral reaction rate proof test at the Cold Vacuum Drying Facility (CVDF). The purpose of the proof test is to measure the reactivity of uranium fuel in an MCO. The proposed direct reactivity measurement tests will measure the rate of release of hydrogen which is a reaction product for uranium metal corrosion. The hydrogen concentration in a helium purge stream will be measured with a spectrometer. A second reactivity measurement approach based on observing the pressure increase in the head space in the MCO after the water has been heated to $50^{\circ} \mathrm{C}$ has also been identified and its feasibility assessed (Appendix A). Each test strategy directly measures the $\mathrm{MCO}$ reactivity for the single given test temperature $\left(50^{\circ} \mathrm{C}\right)$. The MCO reactivity at other temperatures is also needed. This can be estimated by considering the reactivity to be the product of the reaction rate per unit area and the reactive area of the uranium in the given $\mathrm{MCO}$. The available temperature dependent reaction rate data can be used to infer the MCO's reactive area for the $50^{\circ} \mathrm{C}$ measurement temperature. The inferred reactive area is not temperature dependent. It can be used to estimate the MCO reactivity at other temperatures when the available reaction rate data is applied to those other MCO conditions. Measurement inaccuracies and their impact on the feasibility of these measurements are determined.

This feasibility assessment will be based upon the planned facility configuration and instrumentation as currently defined (DRAFT 90\%). The feasibility assessment will also consider the ability to perform the direct reactivity measurements in a reasonable time interval. A period of a shift (approximately 8 hours) or less has been assumed as a reasonable time interval objective. 


\subsection{SUMMARY AND CONCLUSIONS}

It is concluded that the proposed reactivity measurement based on recording the changes in the molar ratio of hydrogen to helium in the purge flow due to the reaction products from the uranium metal water reaction is feasible. The currently planned CVDF design may require some modification for spectrometer sample line. A reasonable, i.e., less than one shift, test duration can likely be used and still assure sufficient accuracy for confidence in the measurement results.

The major conclusions from this feasibility study are

- measurement strategy is feasible given that a means is added to the facility (new equipment) for adding a controlled, low flow of helium to the MCO and removing water vapor from the MCO gas sample supplied to the mass spectrometer. Also, a pressure control system is needed so that the desired MCO pressure ( 100 torr) can be accurately controlled,

- the actual rate law for spent fuel must be confirmed so that the specific test parameters (helium purge rate and test interval) can be established. 


\subsection{ASSUMPTIONS}

The following assumptions have been made in this calculation note:

1. The CVDF tempered water system can establish and maintain thermal equilibrium between the MCO contents (fuel, baskets, internal structures, water and gas head space) during the heatup step of the cold vacuum drying process. Once the heatup to $50^{\circ} \mathrm{C}$ is complete the tempered water system will be run continuously during the direct reactivity measurement to hold a constant temperature of $50^{\circ} \mathrm{C}$. The tempered water system will be capable of removing any decay or reaction heat added during the direct reactivity measurement or add heat to overcome any heat losses to ambient during the test.

2. Fuel basin water added to $\mathrm{MCO}$ is saturated with dissolved air for the local ambient condition which is approximately $15^{\circ} \mathrm{C}$.

3. The attached piping volume can be estimated per (Duncan, 1997a) which is Draft $90 \%$ information. This information is needed if the headspace pressurization rate is used to measure reactivity. A detailed review of the final piping configuration and planned value lineup used during such testing would eventually be needed. The proper volume and its uncertainty range could be used to interpret future measurements.

4. The initial hydrogen concentration in the MCO as delivered to the CVDF is zero. This assumption maximizes the potential for dissolution and the unavailability of hydrogen for the reactivity measurement.

5. Saturated equilibrium can not be established for the gas (oxygen and hydrogen) partitioned between the gas and water regions in the $\mathrm{MCO}$ for the helium purge reactivity measurement scheme which uses an open system.

6. Saturated equilibrium is established for the hydrogen partitioned between the gas and water regions in the $\mathrm{MCO}$ for the pressurization rate reactivity measurement (see Appendix A) which uses a closed system.

7. Reaction rate law for spent fuel is known as a function of temperature.

8. Hydrogen consumption by hydrogen reaction with uranium oxides is negligible because of the relatively low temperature employed during the measurements. The low temperature $\left(50^{\circ} \mathrm{C}\right)$ implies very small kinetic rates for such reactions. 
9. The accuracy of the spectrometer used to measure the hydrogen to helium ratio in the MCO purge exit stream is $\pm 1.0 \%$. This is judged to be a reasonable expectation based on available spectrometer specifications for nitrogen and argon measurements in air. A high degree of accuracy in the measurement of the hydrogen to helium ratio is not a crucial requirement for identifying an order of magnitude value of an MCO's reactivity.

The following input data was used in this calculation:

A. MCO Dimensions and Contents

1. MCO shell dimensions

(Duncan, 1997a)

ID $=23$ in

$\mathrm{OD}=24 \mathrm{in}$

length $=140$ in

2. Fuel volume

(Duncan, 1997a)

Assembly volume $\quad=1.47 \mathrm{\ell}$

Number of $E$ length Mk IV assemblies/MCO $=270$

Number of E length Mk IV assemblies/fuel basket $=54$

3. Fuel Baskets

(Duncan, 1997a)

Basket Volume $\quad=9 \ell$

Number of baskets/MCO $=5$

4. Spent fuel configuration ("rings") in a fuel basket (DrawingH-2-828070)

Ring $\quad \underline{\text { Radius (in) }} \quad$\begin{tabular}{c}
$\begin{array}{c}\text { Number } \\
\text { of Fuel Elements }\end{array}$ \\
\hline
\end{tabular}

Inner (1)

2.75

6

Middle-inner (2)

5.5

12

Middle-outer (3)

8.25

18

Outer (4)

9.526

18 
5. Decay Heat per MCO

(Duncan, 1977c)

Design basis decay heat (Mark IV fuel) $=396 \mathrm{~W}$

B. Physical Properties

1. Volumetric coefficients of Thermal Expansion $(\beta)$

Material

U

Stainless Steel $\frac{\beta}{45.8 \mathrm{E}-6}$

$49.7 \mathrm{E}-6 \mathrm{~K}^{-1}(1)$
(Katz, 1986)

Table 9-2 (Smith, 1967a)

${ }^{(1)}$ Estimated from linear coefficient of thermal expansion $(\alpha)$ by $\beta=3 \alpha$.

2. Water properties (Keenan and Keyes, 1987)

specific volume @ $15^{\circ} \mathrm{C}=1.0009 \mathrm{E}-3 \mathrm{~m}^{3} / \mathrm{kg}$ specific volume@ $50^{\circ} \mathrm{C}=1.0121 \mathrm{E}-3 \mathrm{~m}^{3} / \mathrm{kg}$ thermal conductivity@ $50^{\circ} \mathrm{C}=0.643 \mathrm{~W} / \mathrm{m} / \mathrm{K}$

3. Density

Material

U

Stainless Steel (304) $\quad 7.9$
(Katz, 1986)

Table 9-2 (Smith, 1967)

C. Henry's Law Constant $\mathrm{H}\left(\frac{\text { atm }}{\text { mole solute/mole solution }}\right)$

$\mathrm{H} \quad$ Temperature $\left({ }^{\circ} \mathrm{C}\right)$ Solute $\quad$ Solvent

$\begin{array}{lllll}6.07 \mathrm{E} 4 & 15 & \text { air } & \text { water } & \text { (Perry, 1963) } \\ 9.46 \mathrm{E} 4 & 50 & \text { air } & \text { water } & \text { (Perry, 1963) } \\ 7.65 \mathrm{E} 4 & 50 & \text { hydrogen } & \text { water } & \text { (Perry, 1963) }\end{array}$




$$
\text { HNF-SD-SNF-CN-022, Rev. } 0
$$

FAI/97-32 Page 10 of $4 \delta$

Rev. 0 Date: $5 / 14 \sqrt{97}$

\subsection{SOURCES}

The two principle sources of information used in the feasibility assessment are design data for the CVDF facility and reaction rate data.

The facility configuration used in this assessment is from drawings marked as "DRAFT 90\%". The instrumentation list indicates the planned measurement capabilities and the instrumentation specifications and vendors have been finalized to varying degrees. Once the CVDF design is finalized it would be prudent to confirm that the relevant geometry and process flow information used in this assessment is still appropriate. The mass spectrometer and its sampling scheme also remain to be finalized. The accuracy for the measurement of the ratio of hydrogen to helium in the MCO purge exit stream is assumed to be $\pm 1 \%$ in this feasibility study. This range of accuracy for this pair of gases for the spectrometer should be assured in the final instrument specification.

Temperature dependent reaction rate data for uranium metal in oxygenated and de-oxygenated water has been employed in this feasibility assessment. These data are judged to be sufficient to assess the feasibility of the proposed reactivity measurement technique. The determination of reaction rate data for actual spent fuel in a steam environment is currently being contemplated by the Characterization Program. The assessment of the MCO reactivity measurements eventually conducted at the CVDF should use the spent fuel reaction rate data to facilitate the accuracy in those measurements and the specification of the test parameters. 


\subsection{CALCULATIONS}

This section presents the calculations used to assess the feasibility of MCO reactivity measurements at the CVDF. The impact of test parameter uncertainties and instrumentation accuracy are estimated and test procedure implications are identified.

\subsection{Order of Magnitude Assessment of Test Parameter Uncertainties}

Upon receipt at the CVDF each MCO will contain fuel (loaded in fuel or scrap baskets) and water from the spent fuel basin. A small head space will be established in each $\mathrm{MCO}$ at the spent fuel basin before transfer to the CVDF by removing water through the short draw tube. Each MCO is jacketed by a shielding transfer cask vessel. Upon delivery of the MCO and transfer cask to the CVDF they are located on a process skid. Components, piping, instruments and electrical wiring are mounted on the process skid and piping runs from it to a process hood that provides the process connections for the cold vacuum drying system. After the process hood and shield ring are placed onto the cask and MCO they are bolted in place and an inflatable seal is pressurized. The seal completes the closure of the annulus between the $\mathrm{MCO}$ and cask through which tempered water is pumped to control the temperature of the MCO. Tempered water lines are connected to ports in the cask body so that water is circulated through the annulus. The process consists of heating the exterior of the $\mathrm{MCO}$ up to $50^{\circ} \mathrm{C}$ using the tempered water system. Subsequent steps in the cold vacuum drying process inciude bulk water removal, purging, heating, vacuum drying, etc. The first step in the cold vacuum drying process (heatup of the transfer cask and $\mathrm{MCO}$ ) is of particular interest for this feasibility assessment.

The chemical reactions of import for the direct reactivity measurement by analysis of reaction products are

$$
\begin{aligned}
& \mathrm{U}+2 \mathrm{H}_{2} \mathrm{O} \rightarrow \mathrm{UO}_{2}+2 \mathrm{H}_{2} \\
& 2 \mathrm{U}+3 \mathrm{H}_{2} \rightarrow 2 \mathrm{UH}_{3}
\end{aligned}
$$

The second chemical reaction represents the formation of uranium hydride which may consume 2 - 9\% (Baker, 1965) of the evolved hydrogen. This reaction results in a hydrogen defect and reduces the hydrogen available for the reactivity measurement. 
To establish a safety basis that runaway reactions can be precluded at the CVDF one must be able to define the overall reaction rate. One major uncertainty in defining the overall reaction rate is the surface area of the uranium which is available to react with any residual water which may remain in the MCO following the drying process. The reaction of fuel (uranium) with water in the MCO will lead to the evolution of hydrogen as a reaction product. . The direct reactivity measurement will be conducted by analyzing the amount of hydrogen evolved during each MCO test interval.

The effective uranium surface area can be measured when the water filled $\mathrm{MCO}$ is heated to $50^{\circ} \mathrm{C}$ at the start of the cold vacuum drying cycle. During MCO heating, a vacuum would be established on the MCO and a small controlled flow of helium gas started down the deep leg to the bottom of the MCO. The MCO system pressure is maintained just above the boiling pressure of the water at $50^{\circ} \mathrm{C}(100$ torr). The helium gas which is saturated with water vapor (steam) will sweep out oxygen dissolved in the water and hydrogen being generated by reaction with uranium. A sweep volume of 100 standard $\mathrm{mL} / \mathrm{min}$ of helium injected at the bottom of the $\mathrm{MCO}$ at $50^{\circ} \mathrm{C}$ and 100 torr pressure will expand to over $10 \mathrm{~L} /$ minute of steam - helium mixture (Duncan, 1997b). The total effective void volume is about $30 \mathrm{~L}$ and each volume will provide a $1 / \mathrm{e}$ (well mixed system) approach to steady state. Within 15 minutes the system should be oxygen free and at steady state. Removing oxygen dissolved in the water, which can passivate the uranium surface, ensures the maximum uranium-water reaction rate is measured.

The reaction area analysis will be made by using the measured helium inlet purge rate $\left(\dot{V}_{H e}\right)$ at standard conditions and exit gas hydrogen to helium mole ration $\left(x_{\mathrm{H}_{2}} / x_{\mathrm{He}}\right)$ as determined by the spectrometer.

$$
A=\frac{\dot{V}_{\mathrm{He}}}{\left(\frac{22.4 \ell \mathrm{He}}{g \cdot \text { mole He}}\right)} \frac{x_{\mathrm{H}_{2}}}{x_{\mathrm{He}}}\left(\frac{\dot{n}_{\mathrm{H}_{2}}}{A}\right)^{-1}
$$

where

$\begin{array}{ll}\dot{V}_{H e} & \text { is measured helium purge rate at standard conditions } \\ \frac{x_{H_{2}}}{x_{H e}} & \text { is measured molar ratio of hydrogen to helium in the exit purge flow } \\ \left(\frac{\dot{n}_{H_{2}}}{A}\right) & \begin{array}{l}\text { is the } \mathrm{U}-\mathrm{H}_{2} \mathrm{O} \text { system reaction rate as a function of temperature per unit } \\ \text { area }\end{array}\end{array}$ 
The reaction rate data per unit area of uranium for the $\mathrm{U}-\mathrm{H}_{2} \mathrm{O}$ system for spent fuel is needed to estimate the reactive area of the exposed and unreacted uranium surface in the MCO. It should be recognized that the amount of fuel and its shape and exposed uranium surface area will vary for each MCO such that a specific measurement will be needed for each $\mathrm{MCO}$ to ascertain the appropriate uranium surface area for it. This surface area can then be used in calculations and assessments that contribute to characterizing the process for the CVDF for a variety of conditions.

The key consideration for determining the feasibility of the direct integral reactivity measurement is to ascertain the ability to establish the proper set of initial conditions that would allow the direct application and interpretation of Equation (1). A practical issue for these measurements is the time required to obtain stable data for each $\mathrm{MCO}$.

The helium purge method has been selected over the $\mathrm{MCO}$ head space pressurization reactivity method of reactivity measurement based on this practical consideration. The estimated time for the pressurization measurement could be as long as $8 \mathrm{hr}$ (see Appendix A) to assure sufficient accuracy given the possible uncertainties. The estimated time for the helium purge method is approximately an hour given a well behaved reaction rate characterization. Thus, the two measurement techniques appear to be feasible but the helium purge method appears to provide the most practical approach.

The test parameters and initial conditions which may influence the helium purge direct integral reactivity measurement are screened below to determine their effects and identify suitable means of addressing them.

\subsubsection{Thermal Effects}

The MCO is filled with spent fuel and fuel basin water when it is delivered to the CVDF for processing. Thus, it is initially at ambient conditions which are assumed to be approximately $15^{\circ} \mathrm{C}$. The tempered water system is used to heat the transfer cask, $\mathrm{MCO}$ and the $\mathrm{MCO}$ contents to $50^{\circ} \mathrm{C}$ over an approximate duration of 300 minutes. (see CVDF process flow diagram, H-1-82166.) Any decay heat or exothermic reaction heat liberated during the heating process will simply assist the heatup step by the tempered water system. Once the $\mathrm{MCO}$ and transfer cask are heated to $50^{\circ} \mathrm{C}$ it is assumed in this assessment that the tempered water system will maintain them at a uniform $50^{\circ} \mathrm{C}$. It is further assumed that a thermal equilibrium will be established and maintained by the tempered water system between the MCO contents (fuel, water and gas space). 
Thermal expansion from the initial condition (approximately $15^{\circ} \mathrm{C}$ ) to the desired test temperature of $50^{\circ} \mathrm{C}$ will occur. Thermal expansion of the fuel; fuel baskets and the initial water inventory in the MCO will decrease the gas head space volume. Thermal expansion of the MCO will increase the gas head space volume. The net effect of the thermal expansion of these components and initial water inventory is to reduce the gas head space volume.

During or following this MCO heating step of the CVD process, a vacuum would be established on the MCO and the small controlled helium purge would be started. The helium purge would be supplied to the bottom of the MCO through the long dip tube and the steam, helium and other gases would be removed through the short dip tubes.

The thermal expansion of the $\mathrm{MCO}$ and the water inventory as they are heated from $15^{\circ} \mathrm{C}$ to $50^{\circ} \mathrm{C}$ and any pool swell due to the helium purge must be accommodated by removing water (steam) from the MCO such that the short dip tube is not submerged and remains in the MCO gas head space. This also places an operational requirement of the facility. The sample line for the gas composition measurement must have most of the water removed before the gas sample is delivered to the mass spectrometer.

The establishment of the $50^{\circ} \mathrm{C}$ test condition in the $\mathrm{MCO}$ can be accurately controlled by the CVD tempered water system and aided by the vacuum system attached to the MCO for the cold vacuum drying. The $M C O$ pressure should be reduced to the $50^{\circ} \mathrm{C}$ saturation condition and then accurately controlled. This may also place an operational requirement on the facility. A suitable means of control or throttling the vacuum pump attached to the MCO gas space must be available.

The combination of the helium purge and partial vacuum will mechanically agitate the water in the MCO and help assure thermal equilibrium between the MCO contents. This is highly desirable given the significant temperature dependence of the uranium reaction rate.

\subsubsection{Gas Solubility and Adsorption/Absorption Effects}

Fuel basin water (assumed to be approximately $15^{\circ} \mathrm{C}$ ) is used to fill the $\mathrm{MCO}$ once the spent fuel and scrap baskets have been loaded into the MCO. Since the fuel basin water is open to atmosphere it is assumed in this calculation that it is saturated with dissolved air. When the water in the MCO is heated from $15^{\circ}$ to $50^{\circ} \mathrm{C}$ at approximately $1 \mathrm{~atm}$, the solubility of the dissolved air is reduced and some air will come out of solution as a gas and collect in the free volume (water plus gas spaces) in the $\mathrm{MCO}$. The amount of gas in solution at equilibrium at 
these two temperature conditions can be estimated by applying Henry's law (Perry, 1963). Henry's law states that the solubility of a gas in a solute can be found by

$$
H=p_{A} / x_{A}
$$

where

$\mathrm{H}$ is the Henry's law constant for a given gas (A) for a given temperature

$p_{A}$ is the partial pressure of gas (A) in the gas phase (atm)

$\mathrm{x}_{\mathrm{A}}$ is the mole fraction of the gas (A) in the liquid phase (mole of gas A per mole of solution)

Per Table 14-3 of (Perry, 1963) for air in water at $15^{\circ} \mathrm{C}, \mathrm{H}=6.07 \mathrm{E} 4$ and at $50^{\circ} \mathrm{C} \mathrm{H}=$ 9.46E4. H has the units of (atm)/(mole of air/mole of solution). By considering that the MCO gas head volume is completely filled with air at $1 \mathrm{~atm}$ pressure and applying Equation (2) with these two values of $\mathrm{H}$, the mole fraction of air in water at saturation at $15^{\circ} \mathrm{C}$ is $1.65 \mathrm{E}-5$ and at $50^{\circ} \mathrm{C}$ is $1.06 \mathrm{E}-5$. The difference between these two numbers is the decrease in the solubility of air in water which would result from the heatup of the $\mathrm{MCO}$ and its contents. The reduced solubility will result in air coming out of solution and filling part of the gas head space volume. The change in solubility will result in approximately $2 \mathrm{E}-4 \mathrm{~kg}$ mole of air being released per $\mathrm{kg}$ mole of solution heated to $50^{\circ} \mathrm{C}$.

For the helium purge measurement technique the MCO gas space is an open system. The vacuum system and helium purge both remove gases from the MCO free volume head space. The removal of oxygen decreases its partial pressure $\left(P_{A}\right)$ and reduces the mole fraction $\left(x_{A}\right)$ which can remain in the MCO water. As the equilibrium condition is reduced and the dissolved gases (including oxygen) come out of solution, they are purged out of the water as the helium bubbles through the MCO water inventory. The oxygen concentration can be monitored in the MCO exhaust stream so that the depletion of the dissolved oxygen can be confirmed by direct measurement. Thus, the initial condition of no or very low oxygen concentrations in the MCO water can be established and confirmed. This is important since the uranium reaction rate is known to be effected by the dissolved oxygen concentration during uranium corrosion (Pearce, 1989). If the water surrounding the reacting uranium becomes de-oxygenated during the reactivity measurement then the reaction rate would increase per the data cited in Section 5.2 (see Figure 1). Monitoring of the oxygen content in the exit stream as well as the ratio of hydrogen to helium would be used during each test to demonstrate low oxygen concentrations and a uniform reaction rate. 


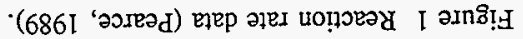

$\mid \frac{7}{6}$

Rate of weight gain, $m g \mathrm{~cm}^{-2} \mathrm{~h}-1$

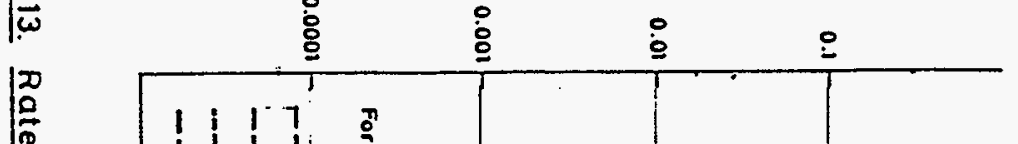

o

2

2

8

$\frac{1}{2}$

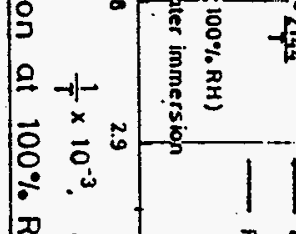

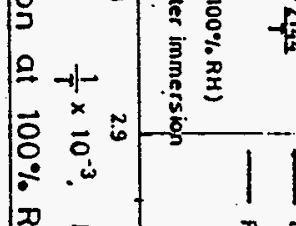

I

ja

5

(5)

$\int_{-1}$

is

|lo

$\int_{0}^{1}$

is

$\int_{10}^{10}$

$\int_{\frac{1}{n}}^{n}$

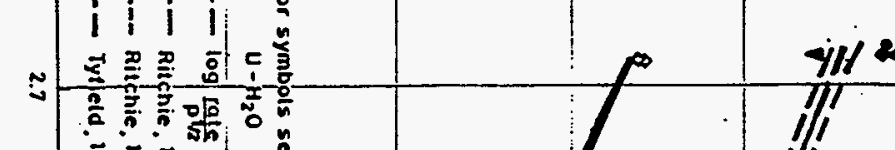

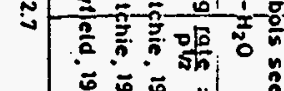
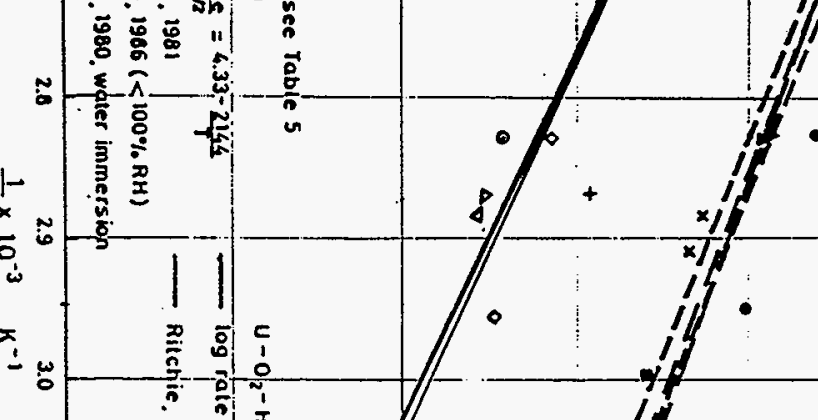


$$
\text { HNF-SD-SNF-CN-022, Rev. } 0
$$

FAI/97-32 Page $\angle 7$ of 48 Rev. 0 Date: $514 \sqrt{97}$

The next gas solubility and adsorption/absorption effects to be considered regarding test parameter uncertainties should address the possibility of hydrogen produced during the reaction of interest "hiding out" in the MCO being tested. By "hiding out" it is meant that as the hydrogen is evolved by the reaction between water and uranium metal it is stored within the system in a manner that does not change the measured hydrogen concentration in the purge stream. Some of the hydrogen would go into solution until the water inventory is saturated with hydrogen at the $50^{\circ} \mathrm{C}$ test condition. As discussed above, the helium purge and partial vacuum will also sparge the hydrogen gas as it is evolved. 'The open system MCO configuration will minimize the amount of hydrogen (if any) that will remain in solution in the MCO water inventory. Furthermore, the evolved hydrogen could be adsorbed onto the solid surfaces and absorbed in the uranium and zircalloy inside the MCO.

Data on adsorption of the evolved hydrogen is not available. Thus, this feasibility study does not attempt to calculate the inventory of evolved hydrogen which would "hide out" as an adsorbed layer on the surfaces inside the $\mathrm{MCO}$ or absorbed in the spent fuel. However, it is known that as hydrogen is absorbed onto the exposed solid surfaces inside the MCO an equilibrium condition can be established such that no further adsorption on the solid surfaces occurs. If this condition is established before the reactivity measurements are taken then no additional adsorption would be expected to occur during the measurement. Alternately, if the measurement interval is long enough the effect of adsorption could be saturated during the initial part of the test and thereby eliminated for the majority of the measurement interval. The on-line measurement of the hydrogen to helium ratio in the purge stream can be used during each test to judge when a steady condition is achieved.

\subsection{Reactivity Assessment}

As discussed in Section 5.1 and shown by Equation (1), the reactivity measurement will collect data on the hydrogen to helium ratio pressure history for the MCO purge and use it to directly infer the reactive area. This calculation will assume that the MCO temperature and temperature dependent reaction rate are known and are constant during the entire test interval which will likely be an hour or less. Several of the test parameter uncertainties which could significantly alter or mask the measurement of the evolution of the reaction products can be addressed by carefully establishing the appropriate set of initial conditions. Section 5.3 discusses these considerations. 
Table 1 summarizes a base case calculation. This table illustrates the calculational procedure including the use of the reactivity rate data and the targeted initial test conditions. As discussed in Table 1, a rate multiplier of one has been used here. An assumed reactive area of $10 \mathrm{~m}^{2}$ is used. The resulting molar ratio of hydrogen to helium for a $10 \mathrm{~m}^{2}$ reactive area is shown to be 0.4 which is well within the resolution possible with the mass spectrometer. Table 2 indicates a detection limit of 50 ppm. Given 100 ppm hydrogen in helium the molar ratio is very small, i.e., $2 \mathrm{E}-4$ which means that the spectrometer could detect very low hydrogen concentrations. Also, a reactive area of only 0.5 $\mathrm{m}^{2}$ would result in a molar ratio of 0.008 which is also within the possible resolution.

The accuracy and range of the pressure, temperature, purge flow and spectrometry instruments are important considerations in assessing the feasibility of the reactivity measurement. Table 2 lists the planned instrumentation including the ranges and accuracy of the sensors. The respective manufacturers were contacted to ascertain the accuracy of the selected instrumentation. Two pressure instruments with ranges from 0 to 10 torr and 0 to 1,000 torr are provided. The accuracy of the selected pressure instruments is $\pm 0.5 \%$ of the reading. This combination of instrument ranges and accuracy could provide sufficient resolution to monitor the hydrogen which could be produced by the reaction products from the reaction of interest.

An assessment of the impact of instrument errors and accuracy is provided here. The MCO pressure will be controlled during its heat-up to $50^{\circ} \mathrm{C}$ by the tempered water and vacuum systems. The desired pressure which corresponds to the saturation condition at $50^{\circ} \mathrm{C}$ is $12.35 \mathrm{~K} \mathrm{~Pa}$ ( 95 torr). The

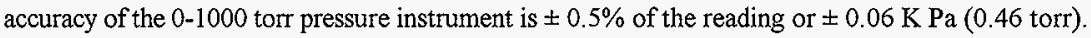
The pressure at the bottom of the $\mathrm{MCO}$ is much higher due to hydrostatic head but, recirculation of the water in the MCO will maintain the temperature close to the surface temperature. The corresponding range in the system temperature due to this range of variation in the pressure measurement is $\pm 0.1^{\circ} \mathrm{C}$. The combined impact on the inferred reaction area of the inaccuracies in the pressure measurement and concomitant variation in the corresponding saturated water temperature is small ( $\pm 0.6 \%$ variation in $\mathrm{k}$ as shown in Table 3 ). This variation is smaller than the data scatter used to derive the reaction rate correlation. Table 3 also assess the potential impact for variation from thermal equilibrium at $50^{\circ} \mathrm{C}$ and its impact on the reaction rate. This impact on the accuracy of the reactivity measurement is discussed below. 
Table 1

Base Case Reactive Area Estimate

An MCO with a full fuel load ( 270 assemblies) is assumed to be installed in the CVD process skid and its initial condition set:

$$
\begin{aligned}
& \mathrm{T}=50^{\circ} \mathrm{C}(323 \mathrm{~K}) \\
& \dot{V}_{H e}=100 \mathrm{~m} / / \text { minute }=1.67 \mathrm{E}-3 \ell / \mathrm{s}
\end{aligned}
$$

Per Figure 1 the temperature dependent reaction rate per unit area (k) for the $\mathrm{U}-\mathrm{H}_{2} \mathrm{O}$ system at $323 \mathrm{~K}$ can be calculated from

$$
\log \left(\frac{k}{p^{1 / 2}}\right)=4.33-\frac{2144}{T}
$$

where

$$
\begin{aligned}
& \mathbf{k} \text { is the reaction rate (weight gain) in } \mathrm{m}_{\mathrm{g}} \mathrm{O} \mathrm{cm}^{-2} \mathrm{hr}^{-1} \\
& \mathrm{p} \\
& \mathrm{T} \\
& \text { is the water vapor pressure in } \mathrm{kPa}
\end{aligned}
$$

However, this expression is based on data for unirradiated uranium. Research indicates that irradiation and surface roughness effects could cause the reaction rate to increase by a factor of 2 to 10. If it is assumed that the shape of the rate law is the same (i.e., only a function of temperature) then a simple multiplier $(\mathrm{M})$ can be used to represent these effects

$$
\log \left(\frac{k}{M p^{1 / 2}}\right)=\left(4.33-\frac{2144}{T}\right)
$$

A value of one will be used for $M$ in this base case assessment. However, this is an unresolved item which must be addressed before the test interval can be specified and actual helium purge rate is established. At $50^{\circ} \mathrm{C}$ the vapor pressure for water is $12.35 \mathrm{kPa}$ so

$$
\log \left(\frac{k}{12.35^{0.5}}\right)=\left(4.33-\frac{2144}{323}\right)=-2.308
$$




\section{Table 1 - Continued}

$$
k=1.7 E-2 \frac{m g O}{\mathrm{~cm}^{2} h r}
$$

A convenient reaction rate unit is $\mathrm{g}$ mole $\mathrm{H}_{2} / \mathrm{m}^{-2} \mathrm{sec}^{-1}$ and the appropriate conversion factor is

$$
\frac{1 \mathrm{mg} O}{\mathrm{~cm}^{2} \mathrm{hr}} \times \frac{1 \mathrm{hr}}{3600 \mathrm{~s}} \times \frac{1 \mathrm{~g}}{10^{3} \mathrm{mg}} \times \frac{10^{4} \mathrm{~cm}^{2}}{\mathrm{~m}^{2}} \times \frac{1 \mathrm{~g} \text { mole } \mathrm{O}}{16 \mathrm{~g} O} \times \frac{1 \mathrm{~g} \text { mole } \mathrm{H}_{2}}{1 \mathrm{gmole} \mathrm{O}} \frac{\mathrm{g} \text { mole } H_{2}}{\mathrm{~m}^{2} \mathrm{~s}}=1.736 \mathrm{E-4}
$$

So,

$$
\frac{\dot{n}_{H_{2}}}{A} @ 50^{\circ} \mathrm{C}=2.95 E-6 \frac{g \text { mole } H_{2}}{m^{2} s}
$$

The actual exposed surface area of uranium metal is unknown and is the object of conducting the reactivity measurement. However, if a reactive surface area range of $10 \mathrm{~m}^{2}$ to $0.5 \mathrm{~m}^{2}$ is assumed the expected molar ratio in the purge exit can be estimated.

Per Equation (1) the ratio of hydrogen to helium in the purge flow is

$$
\begin{aligned}
\frac{x_{H_{2}}}{x_{H e}} & =\left(\frac{\dot{n}_{H_{2}}}{A}\right) A\left(\frac{1}{\dot{V}_{H e}}\right)\left(\frac{22.4 \ell H e}{g \cdot \text { mole He}}\right) \\
\frac{x_{H_{2}}}{x_{H e}} & =2.95 E-6 \frac{g \cdot \text { mole } H_{2}}{m^{2} s}\left(A m^{2}\right)\left(\frac{1}{1.67 E-3 \frac{\ell \text { of } H e}{s}}\right)\left(\frac{22.4 \ell H e}{g \cdot \text { mole He }}\right) \\
& =0.4 \frac{g \cdot \text { mole } H_{2}}{g \cdot \text { mole } H e} \text { for } 10 \mathrm{~m}^{2} \text { reactive area } \\
& =0.008 \frac{g \cdot \text { mole } H_{2}}{g \cdot \text { mole } H e} \text { for } 0.5 \mathrm{~m}^{2} \text { reactive area }
\end{aligned}
$$


Table 2

Test Instrumentation Ranges and Accuracy

\begin{tabular}{|c|c|c|c|c|c|}
\hline $\begin{array}{l}\text { Component } \\
\text { Description }\end{array}$ & Tag & Manufacturer & $\begin{array}{c}\text { Model } \\
\text { Number }\end{array}$ & Range & Accuracy \\
\hline $\begin{array}{l}\text { Pressure Indicator } \\
\text { and Transmitter }\end{array}$ & $\begin{array}{l}\text { PI-1*08 } \\
\text { PT- } 1 * 08\end{array}$ & $\begin{array}{c}\text { MKS } \\
\text { Instruments } \\
\text { Inc. }\end{array}$ & $\begin{array}{l}\text { 230DA- } \\
\text { O0010BBB }\end{array}$ & $0-10$ torr $^{(1)}$ & $\begin{array}{l} \pm 0.5 \% \text { of } \\
\text { reading }\end{array}$ \\
\hline $\begin{array}{l}\text { Pressure Indicator } \\
\text { and Transmitter }\end{array}$ & $\begin{array}{l}\text { PI }-1 * 10 \\
\text { PT }-1 * 10\end{array}$ & $\begin{array}{l}\text { MKS } \\
\text { Instruments } \\
\text { Inc. }\end{array}$ & $\begin{array}{l}230 \mathrm{DA}- \\
01000 \mathrm{BBB}\end{array}$ & $0-1000$ tors $(1)$ & $\begin{array}{l} \pm 0.5 \% \text { of } \\
\text { reading }\end{array}$ \\
\hline $\begin{array}{l}\text { Temperatusre } \\
\text { Elements }\end{array}$ & $\begin{array}{l}\text { TE-1*07 } \\
\text { TE-2*14 } \\
\text { TE-2*15 } \\
\text { TE-2*18 } \\
\text { TE-3*05 } \\
\text { TE-3*12 } \\
\text { TE-3*13 }\end{array}$ & $\begin{array}{l}\text { MTI Industrial } \\
\text { Sensors }\end{array}$ & $\begin{array}{c}\text { RC-4-9-A" } \\
\text {-D-3-P10 } \\
\text {-H012-TTC } \\
-B 11\end{array}$ & $0.400 \mathrm{~F}$ & $\begin{array}{l} \pm 1 \% \text { full } \\
\text { scale }\end{array}$ \\
\hline $\begin{array}{l}\text { Gas Analyzer } \\
\text { (Spectrometer) }\end{array}$ & & $\begin{array}{c}\text { Balzers } \\
\text { Instruments }\end{array}$ & QMS200 & $1-200 \mathrm{amu}^{(2)}$ & $\pm 1 \%^{(3)}$ \\
\hline $\begin{array}{l}\text { Mass Flow Meter } \\
\text { and Controller }\end{array}$ & (4) & (4) & (4) & $0-1389 \mathrm{SCCM}$ & $\pm 1 \%^{(5)}$ \\
\hline
\end{tabular}

(1) Maximum service conditions are 5 psi and $140^{\circ} \mathrm{F}$. Overpressure limit is 35 psia.

(2) Detection limit is less than $50 \mathrm{ppm}$.

(3) Assumed accuracy for ratio of hydrogen to helium in a sample stream.

${ }^{(4)}$ Specific meter not yet selected; current facility design does not include a mass flow meter.

(5)Typical values. 
Table 3

Impact of Variations in the MCO Temperature

\section{Variations Due to Pressure Measurement}

The accuracy of the pressure measurement is $\pm 0.5 \%$. The desired MCO pressure to set the corresponding saturation temperature of $50^{\circ} \mathrm{C}$ is $12.35 \mathrm{KPa}$. Thus, the instrument accuracy could result in a pressure variation of $\pm 0.06 \mathrm{KPa}$ which corresponds to a temperature variation of $\pm 0.1 \mathrm{~K}$.

As defined in Table 1 the reaction rate for the $\mathrm{U}-\mathrm{H}_{2} \mathrm{O}$ system is given as

$$
\log \left(\frac{k}{M p^{1 / 2}}\right)=4.33-\frac{2144}{T}
$$

Taking $M=1$, the range in $\mathrm{k}$ due to a variation in the actual $\mathrm{MCO}$ pressure can be determined by calculating $\mathrm{k}$ for the following three sets of parameters:

\begin{tabular}{|c|c|c|}
\hline $\mathrm{P}(\mathrm{Kpa})$ & $\underline{T(K)}$ & $k$ \\
\hline 12.35 & 323 & $1.73 \mathrm{E}-2$ \\
\hline 12.41 & 323.1 & $1.74 \mathrm{E}-2$ \\
\hline 12.29 & 322.9 & $1.72 \mathrm{E}-2$ \\
\hline
\end{tabular}

The resulting range in the variation in $\mathrm{k}$ is $\pm 1 \mathrm{E}-4$ which compared to a value of $\mathrm{k}$ for the desired initial conditions of $1.73 \mathrm{E}-2$ is a $\pm 0.6 \%$ variation in $k$.

\section{Variations Due to Thermal Equilibrium Effects}

The tempered water system will submerge the $\mathrm{MCO}$ in a $50^{\circ} \mathrm{C}$ bath. The decay heat from the spent fuel is a heat source which could cause the MCO's temperature to exceed the $50^{\circ} \mathrm{C}$ bath temperature. A bounding estimate of the variation from thermal equilibrium is provided below. It ignores any circulation in the MCO water or enhanced heat transfer and mixing due to the helium purge. The $\mathrm{MCO}$ and its contents are idealized as a composite material of cylindrical geometry with a distributed internal heat source. A constant surface temperature $\left(50^{\circ} \mathrm{C}\right)$ boundary condition is considered. 
Table 3

Impact of Variations in the MCO Temperature (continued)

The conduction equation for a solid cylindrical geometry with a uniform distributed heat source yields the following equation

$$
\Delta T=\frac{q^{\prime \prime} r^{2}}{4 k_{c}}
$$

where

$$
\begin{aligned}
& \Delta \mathrm{T} \quad=\text { temperature difference between cylinder centerline and radial position, } \mathrm{r} . \\
& \mathrm{q} \quad=\text { radial position measured from centerline } \\
& \mathrm{k}_{\mathrm{c}} \quad=\text { volumetric heat source }
\end{aligned}
$$

The value of $\mathrm{k}$ for the composite material (spent fuel and water) can be estimated from the porosity (volume fraction of fuel), p, per (Perry, 1963) as follows

$$
k_{c}=\frac{k_{w}}{\left(1-p^{1 / 3}\right)}
$$

where $k_{w}$ thermal conductivity of water (continuous phase).

These equations can be used to assess the maximum deviation of the thermal variation at the $\mathrm{MCO}$ centerline and at the radius of each ring of spent fuel. Given that

$$
\begin{aligned}
q^{\prime \prime} & =\frac{M C O \text { total decay power }}{\text { volume of five fuel baskets }} \\
& =\frac{396 \mathrm{~W}}{5(\pi)(0.292 \mathrm{~m})^{2}(0.663 \mathrm{~m})}=446{\mathrm{~W} / \mathrm{m}^{3}}^{3} \\
p & =\frac{\text { cross sectional area of fuel }}{\text { cross sectional area of } M C O}
\end{aligned}
$$




\section{Table 3}

Impact of Variations in the MCO Temperature

(continued)

$$
\begin{aligned}
& =\frac{\left(\frac{\text { volume of fuel in one basket }}{\text { height of fuel basket }}\right)}{\text { cross sectional area of } M C O} \\
& =\frac{\left(\frac{54\left(1.47 E-3 m^{3}\right)}{0.663 \mathrm{~m}}\right)}{\frac{\pi}{4}(23 \times .0254 \mathrm{~m})^{2}}=0.45 \\
& k_{c}=\frac{k_{w}}{\left(1-0.45^{1 / 3}\right)}=k_{w}(4.28) \\
& k_{c}=0.643 \frac{W}{m K}(4.28)=2.75 \frac{W}{m K} \\
& \text { r } \quad \Delta \mathrm{T} \quad \mathrm{T} @ \mathrm{r} \\
& \text { Location (m) } \quad\left({ }^{\circ} \mathrm{K}\right) \quad\left({ }^{\circ} \mathrm{C}\right) \\
& \begin{array}{llll}
\text { Ring 1 } & 0.07 & 0.2 & 53.3
\end{array} \\
& \begin{array}{llll}
\text { Ring } 2 & 0.14 & 0.8 & 52.7
\end{array} \\
& \begin{array}{llll}
\text { Ring } 3 & 0.21 & 1.8 & 51.7
\end{array} \\
& \begin{array}{llll}
\text { Ring } 4 & 0.24 & 2.3 & 51.2
\end{array} \\
& \begin{array}{llll}
\text { MCO } & 0.29 & 3.5 & 50.0
\end{array}
\end{aligned}
$$

The impact of the bounding radial temperature variation of $3.5 \mathrm{~K}$ on the reaction rate with $\mathrm{M}$ $=1$ and $\mathrm{p}=12.35 \mathrm{KPa}$ (as used above) is found by evaluating the reaction rate law at $326.5^{\circ} \mathrm{K}$ and dividing by the reaction rate, $\mathrm{k}(1.73 \mathrm{E}-2)$, for $323^{\circ} \mathrm{K}$. 


\section{Table 3}

\section{Impact of Variations in the MCO Temperature (continued)}

$$
\begin{aligned}
& k @ 326.5^{\circ} \mathrm{K}=2.04 E-2 \\
& \frac{k @ 326.5 \mathrm{~K}}{k @ 323 \mathrm{~K}}=\frac{2.04 E-2}{1.73 E-2}=1.18
\end{aligned}
$$

A variation of $3.5^{\circ} \mathrm{K}$ from thermal equilibrium would result in a maximum uncertainty in the measured reaction rate of approximately $20 \%$ if it is assumed that all the spent fuel experienced this maximum variation from the intended temperature of $50^{\circ} \mathrm{C}$.

Additionally, this radial variation in temperature will be reduced near the top of the MCO and become zero at the water surface due to the partial vacuum established in the MCO gas space. Boiling will occur near the surface. However, once the total local pressure (including hydrostatic head) exceeds the vapor pressure for the local water temperature the boiling will stop. This will occur at approximately 10 inches beneath the water surface for the planned test conditions.

A refined estimate of the impact of the variation from thermal equilibrium can be made by including the radial temperature distribution. The spent fuel in each ring will be at a different temperature and will experience different degrees of variation from the desired $50^{\circ} \mathrm{C}$ value. A mean reaction rate where the reaction rate for each fuel ring's temperature is weighted by the fraction of spent fuel in that ring can be estimated as follows

$$
\bar{k}=\frac{\sum_{i}\left(\begin{array}{c}
\text { number of fuel elements } \\
\text { in each ring of } \\
\text { a fuel basket }
\end{array}\right) k\left(T_{i}\right)}{\left(\begin{array}{c}
\text { Total number } \\
\text { of fuel elements in a } \\
\text { fuel basket }
\end{array}\right) k(50)}
$$

where

i number of fuel ring

$k\left(T_{j}\right)$ reaction rate for temperature of $i^{\text {th }}$ ring

$\mathrm{k}(50)$ reaction rate for $50^{\circ} \mathrm{C}$ 


$$
\text { HNF-SD-SNF-CN-022, Rev. O }
$$

FAI/97-32 Page 26 of 48

Rev. 0 Date: $5 / 14797$

\section{Table 3}

Impact of Variations in the MCO Temperature (continued)

Substituting the appropriate values

$$
\begin{aligned}
& \bar{k}=\frac{6(2.02 E-2)+12(1.96 E-2)+18(1.867 E-2)+18(1.83 E-2)}{54} \\
& \bar{k}=1.89 E-2
\end{aligned}
$$

This is a factor of 1.09 times the rate at $50^{\circ} \mathrm{C}$ and shows that the influence of a radial temperature gradient and radial fuel distribution is to reduce the potential uncertainty due to a variation in thermal equilibrium. 
The other measured quantities used to conduct the reactivity measurement are the helium purge rate and the molar ratio of hydrogen to helium in the exit stream. The calculated reactive area is directly proportional to the variation in this quantities which per Table 2 are given as $\pm 1 \%$ for the flow rate and $\pm 1 \%$ for the gas analyzer.

The inaccuracy in the inferred reaction area is equal to the product of the inaccuracy of each of the three terms in Eq. (1) used to calculate the reaction area

$$
\text { Area Accuracy }=\left(\begin{array}{c}
\text { Flow Rate } \\
\text { Accuracy }
\end{array}\right) \times\left(\begin{array}{c}
\text { Mole Ratio } \\
\text { Accuracy }
\end{array}\right) \times\left(\begin{array}{c}
\text { Reaction } \\
\text { Rate } \\
\text { Variation }
\end{array}\right)
$$

If the maximum positive variation in each quantity is taken

$$
\text { Area Accuracy }=(1.01)(1.01)(1.06)=1.08
$$

which implies an over estimate of $8 \%$. Likewise, if the extreme negative variation in each quantity is taken

$$
\text { Area Accuracy }=(0.99)(0.99)(0.94)=0.92
$$

which implies an under estimate of $8 \%$. Thus, the inaccuracies in the selected instrumentation could lead to an uncertainty in the inferred reaction area of the order of $\pm 10 \%$. This is well within the desired range of an order of magnitude measurement of the reactive area which has been judged to be sufficient for the CVDF safety assessments.

As discussed in Section 5,1, uranium hydride formation could consume between 2 and $9 \%$ of the hydrogen evolved from the reaction of uranium and water. This hydrogen consumption would also contribute to the inaccuracy in the inferred reaction area as it could reduce the moles of hydrogen detected in the helium purge by as much as $10 \%\left(\frac{1}{1-0.09}\right)$. A reduction in the moles of hydrogen detected would lead to a reduction in the inferred reaction area. Thus, the combined effect of instrument inaccuracies and up to $9 \%$ hydride formation could result in an extreme negative variation of $0.83(0.92 \times 0.9)$ which implies a combined under estimate of $17 \%$. 
Lastly, Table 3 assess the potential impact of variation from thermal equilibrium within the MCO. This effect is estimated to be approximately $9 \%$ which would increase the actual reaction rate and lead to an over estimate of the inferred reaction area. Thus, the combined effect of instrument inaccuracies and variations from thermal equilibrium could result in an extreme positive variation of $1.18(1.08 \times 1.09)$ which implies a combined over estimate of $18 \%$.

Thus, the combined effects of extreme instrumentation inaccuracies, hydrogen consumption by the hydride reaction and variation from thermal equilibrium would lead to an uncertainty in the inferred reaction area of the order of $\pm 20 \%$. This is also well within the desired range of accuracy.

The other significant uncertainty is the reaction rate correlation to be used for the spent fuel. The oxidation (corrosion) rate for the spend fuel can be irradic. Furthermore, as pointed out by (Flament, 1997), the reaction rate between the uranium metal and MCO water can be dependent upon the temperature, oxygen content in MCO water and fuel swelling. The first two dependencies have been discussed above and should be controllable in the planned measurement. Irradiation effects on the reaction rate such as swelling are the subject of research being contemplated by the Characterization Program. The uncertainty in the reaction rate for spent fuel should be quantified and used when the actual reactivity measurements are conducted. As discussed in Table 1, a factor $(M)$ can potentially be used to capture the uncertainty associated with spent fuel effects. Once the uncertainty is characterized it should be used to prescribe the details of the reactivity measurement test. Specifically, the helium purge rate and test interval should be based on the expected amount of hydrogen to be evolved during the test. The rate multiplier will influence these parameters. However, the value of the rate law multiplier is not important when an MCO's reactivity measured at $50^{\circ} \mathrm{C}$ is extrapolated to some other temperature. The extrapolation calculation will result in the rate multiplier cancelling from the final equation.

\subsection{Measurement Procedure Considerations}

The feasibility of the direct reactivity measurement will require the careful establishment of the initial test conditions to accommodate the effects of thermal expansion during the heatup step of the cold vacuum drying process and the dissolved air (oxygen) in the MCO water inventory. The following actions should be addressed in the test procedure that establishes the initial conditions for these open system measurements. 
1. The MCO should be vented during the heatup step to allow escape of any air that comes out of solution from the fuel basin water.

2. The planned gas head volume should be confirmed and reestablished by removing water through the short draw tube. This will correct for the change in water volume during the heatup step and swelling during the helium purge and assure that a gas space volume is established for purging helium.

3. The helium purge through the MCO (in through the long dip tube and out through the short dip tube) should be established. It should be maintained while the oxygen content in the exit stream is monitored to assure that the dissolved oxygen is sparged from the MCO water inventory.

4. The helium purge rate during the reactivity measurement should be recorded so that any variations can be identified and used (if necessary) when the data is processed.

5. The molar ratio of hydrogen to helium should be monitored and recorded. Once the dissolved oxygen has been removed from the MCO water inventory, the molar ratio should be monitored to observe if a constant value is obtained. A constant value would indicate a steady state condition. This would imply that any hydrogen adsorption or absorption effects had been saturated. 


\subsection{REFERENCES}

Barker, M. McD., et al., 1965, Uranium Compatibility Studies. Part 6: The Products and Mechanism of the Uranium-Water and Uranium Hydride-Water Reaction, United Kingdom Atomic Energy Authority, AWRE Report No. 0-45/65, July.

Drawing No. H-1-82166, Rev. K, Cold Vacuum Drying Facility Process Flow Diagram (DRAFT 90\%).

Drawing No. H-2-828070, Rev. C, MCO MARK IV SNF Storage Basket (DRAFT 90\%).

Duncan, D. R., 1997a, Memorandum: Transmittal of Information Needs for Reaction Rate Proof Test at CFD, March 17, 1997.

Duncan, D. R., 1997b, Telefax: Reactivity Measurement, March 27, 1997 (6:12 A.M.).

Duncan, D. R., 1977c, Spent Nuclear Fuel Project Technical Databook, HNF-SD-SNF-TI-015, Rev. 1.

Flament, T. A., 1997, Telefax from D. R. Duncan: Reactivity Measurement, March 28, 1997 (10:47 A.M.).

Katz, J. J., et al., 1986, The Chemistry of the Actinide Elements, Second Edition, Chapman and Hall Ltd., Vol. 1, pp. 228-230.

Keenan, J. M. and Keyes, F. G., 1987, Steam Tables (Thermodynamic Properties of Water Including Vapor, Liquid, and Solid Phases) (SI Units), John Wiley \& Sons, Inc.

Pearce, R. J., 1989, A Review of the Rates of Reaction of Unirradiated Uranium in Gaseous Atmospheres, Central Electricity Generating Board, Berkely Nuclear Laboratories, $\mathrm{RD} / \mathrm{B} / 6231 / \mathrm{R} 89$.

Perry, J. HJ., 1963, Chemical Engineers' Handbook, McGraw-Hill, Inc., Fourth Edition, Chapters 3 and 14.

Smith, C. O., 1967, Nuclear Reactor Materials, Addison-Wasley Publishing Co., Inc. 


\section{HNF-SD-SNF-CN-022, Rev. 0}

\section{ATTACHMENT A}




$$
\text { HNF-SD-SNF-CN-022, Rev. } 0
$$

FAI/97-32 Page $\frac{31}{5 / 14 / 97}$ f $\frac{48}{4}$
Rev. 0 Date:

\section{APPENDIX A - Closed MCO Reactivity Measurement}

A reactivity measurement approach based on a closed MCO is assessed in this appendix. For a closed system the reaction products from the corrosion of uranium metal in water could be detected by monitoring the pressurization of the MCO over a given test interval. This approach is judged to be feasible given that a long enough test interval ( $\sim 8$ hours) is used to assure sufficient accuracy in the inferred reaction area. However, the open system approach using a helium gas purge is also feasible but requires less time to perform. This major advantage of less time leads to the selection of the helium purge approach over the MCO pressurization approach.

The assessment of the MCO pressurization approach is simply documented here for background information regarding this alternate reactivity measurement approach. If this approach is to be pursued further, the steps for conducting such a test could be pursued in more detail at that time. For example, the possibility of de-oxygenating the MCO water inventory could be more rigorously quantified. More explicit guidance on how to use the data collected during such an oxygenated to a de-oxygenated state could be developed. Further, a brief inert gas purge following MCO heatup could be used to mechanically mix the water inventory and further assure that the assumption of thermal equilibrium is valid.

\section{A.1 Assessment of Test Parameter Uncertainties for Pressurization Rate Measurements}

The analysis would be made by using the ideal gas law and the observed pressure change as hydrogen gas is added to the gas head space volume in the MCO and its attached piping.

$$
\dot{P}=\dot{n}_{H_{2}} \frac{R T_{M C O}}{V}
$$

where
$\dot{P} \quad$ is measured rate of pressure change in $\mathrm{MCO}$
$\dot{n}_{H_{2}}$ is the hydrogen evolution rate (moles/sec)
$R \quad$ is ideal gas constant
$T_{M C O}$ is the gas head space temperature
$V$ is the gas head space and attached processing pipe volume

Reaction rate data per unit area of uranium for the $\mathrm{U}-\mathrm{O}_{2}-\mathrm{H}_{2} \mathrm{O}$ system is available. The product of the uranium reaction area and the reaction rate data per unit area can be used to estimate the hydrogen evolution rate. The reaction rate data is given as a function of temperature. 


$$
\dot{P}=\left(\frac{\dot{n}_{H_{2}}}{A}\right) A \frac{R T_{M C O}}{V}
$$

where

$\frac{\dot{n}_{H_{2}}}{A}$ is calculated from the $\mathrm{U}-\mathrm{O}_{2}-\mathrm{H}_{2} \mathrm{O}$ system reaction rates which is given as a $\log \frac{\mathrm{k}}{\mathrm{M}}=8.333-\frac{3730}{\mathrm{~T}}$ where rate data $(\mathrm{k})$ is in units of $\mathrm{mg}$ of oxygen added accounts for uncertainty (see Table 4)
A is the reactive area of the uranium
$\mathrm{T}$ is the $\mathrm{U}-\mathrm{O}_{2}-\mathrm{H}_{2} \mathrm{O}$ system temperature (taken as $\mathrm{T}_{\mathrm{MCO}}$ )

Equation (A-2) shows that by knowing the temperature of the system and the volume of the gas head space that measurements of the rate of pressure change in the MCO can be used to directly calculate the reactive area of the exposed uranium surface in the MCO. It should be recognized that the amount of fuel and its shape and exposed uranium surface area will vary for each MCO such that a specific measurement will be needed for each $\mathrm{MCO}$ to ascertain the appropriate uranium surface area for it. This surface area can then be used in calculations and assessments that establish the safety basis for the CVDF.

The key consideration for determining the feasibility of the direct reactivity measurement is to ascertain the ability to establish the proper set of initial conditions that would allow the direct application and interpretation of the expression in Equation (A-2). The measurement of the observed pressure change for a given interval of time for an $\mathrm{MCO}$ could then be used to quantify the reactive surface area of the fuel in that MCO. Test parameter uncertainties which may influence the direct reactivity measurement are screened below to determine the dominant effects and identify suitable means of addressing them.

\section{A.1.1 Thermal Effects}

The volume change of each component is assessed by estimating its growth due to the change in temperature from 15 to $50^{\circ} \mathrm{C}$ as follows:

$$
\Delta V=\beta V \Delta T
$$

where 
$\Delta V$ is volumetric change of component

$\beta \quad$ is volumetric coefficient of expansion for given material

$V \quad$ is initial volume of component at reference temperature $\left(15^{\circ} \mathrm{C}\right)$

$\Delta T$ is temperature change $\left(50-15=35^{\circ} \mathrm{C}\right)$ that causes thermal growth

The volume change of the water in the MCO is estimated from the change in the specific volume of water between the two saturated water temperatures. The change in specific volume is multiplied by the initial water volume which can vary between given MCOs due to variability in the amount of spent fuel and scrap material which can be placed in each MCO. Per (Duncan, 1997a) the reasonable range in MCO free volume (gas head volume plus water volume) is 500 to $820 \ell$ and the estimated initial gas head space volume will be $15.4 \ell$. Thus, the reasonable range in water volume within a MCO as delivered to the CVDF is 485 to $815 \ell$.

Table A-1 summarizes the thermal expansion assessment during the heatup of the $\mathrm{MCO}$ and transfer cask to $50^{\circ} \mathrm{C}$. A negative sign has been used to indicate a decrease in the planned gas head space volume and a positive sign has been used to indicate a potential increase. The thermal expansion effects are calculated for a change from the initial $15^{\circ} \mathrm{C}$ condition to the $50^{\circ} \mathrm{C}$ condition and assume thermal equilibrium at each condition between the $\mathrm{MCO}$, fuel, fuel baskets, water and gases within the MCO. The estimated net decrease in the planned gas head space volume is between 4 and 8 liters. This would represent a significant fraction of the planned gas space head volume of 15.4 liters. The total gas space available for collecting evolved hydrogen during the reactivity measurement is the sum of the attached process piping and the gas head space in the MCO. Per (Duncan, 1997a) the external piping at the time of their reactivity measurement tests is estimated to be 27.5 feet of 2 inch pipe and 5.25 feet of quarter inch tubing. The volume of this piping and tubing is approximately 18.3 liters. Therefore, the combined gas space would be the sum of 15.4 liters and 18.3 liters or approximately 33.7 liters. The estimated net change in gas head space volume during heatup of 4 - 8 liters is also a significant fraction of the combined gas volume. This would have a direct impact on the magnitude of the reactive area calculated from the observed pressure change during the reactivity measurement since such a calculation assumes a known value of the gas volume in the $\mathrm{MCO}$ and attached piping. The effects of thermal expansion can be addressed by assuring the proper initial conditions are established for the MCO and attached piping following heatup to $50^{\circ} \mathrm{C}$. The reactivity measurement procedure should insure that the change in the water volume is removed such that the initial water volume is reduced to the elevation corresponding to the short dip tube in the top of the $\mathrm{MCO}$ prior to the pressurization measurement. 


\section{Table A-1}

Thermal Expansion Assessment for $35^{\circ} \mathrm{C}$ Temperature Change

\begin{tabular}{llcc}
\hline & $\begin{array}{c}\text { Volumetric } \\
\text { Expansion }(\beta)\end{array}$ & $\begin{array}{c}\text { Initial } \\
\text { Volume }(\ell)\end{array}$ & $\begin{array}{c}\text { Gas Head Space } \\
\text { Volume Change } \\
\text { During Heatup }(\ell)\end{array}$ \\
\hline $\begin{array}{l}\text { Fuel } \\
\text { (uranium) }\end{array}$ & $45.8 \mathrm{E}-6 \mathrm{~K}^{-1}$ & $400^{(2)}$ & -0.4 \\
$\begin{array}{l}\text { Fuel Baskets } \\
\text { (stainless steel) }\end{array}$ & $49.7 \mathrm{E}-6 \mathrm{~K}^{-1}$ & 45 & \\
$\begin{array}{l}\text { MCO Cylindrical } \\
\text { Shell (Stainless }\end{array}$ & $49.7 \mathrm{E}-6 \mathrm{~K}^{-1}$ & $1.2 \mathrm{E} 3$ & -0.07 \\
steel) & & & +2.1 \\
Water & N/A & 485 & -5.4 \\
& & 815 & -9.1 \\
\hline
\end{tabular}

${ }^{(1)}$ Assumed to be all uranium; neglect zircalloy mass

(2) Assumed $270 \mathrm{E}$ length Mk IV assemblies

${ }^{(3)}$ Initial volume of MCO cylindrical shell $=\frac{\pi}{4}\left(24^{2}(2.54)^{2}-23^{2}(2.54)^{2}\right)(140)(2.54)$

$$
=1.21 \mathrm{E} 6 \mathrm{~cm}^{3}=1.2 \mathrm{E} 3 l
$$


A second test parameter thermal effect is the sustained $\mathrm{MCO}$ temperature during the measurement interval. The tempered water system in the CVDF will be used to heatup the $\mathrm{MCO}$ and maintain its temperature at $50^{\circ} \mathrm{C}$. The accuracy of this temperature control could influence the actual temperature of the $\mathrm{MCO}$ and its contents during the measurement interval. The sensitivity of the planned measurement strategy is discussed in Section A.1 (see Table A-6).

\section{A.1.2 Gas Soluability and Absorption Effects}

Fuel basin water (assumed to be approximately $15^{\circ} \mathrm{C}$ ) is used to fill the $\mathrm{MCO}$ once the spent fuel and scrap baskets have been loaded into the MCO. Since the fuel basin is open to atmosphere it is assumed in this calculation that it is saturated with dissolved air. When the water in the $\mathrm{MCO}$ is heated from $15^{\circ}$ to $50^{\circ} \mathrm{C}$ at approximately $1 \mathrm{~atm}$, the solubility of the dissolved air is reduced and some air will come out of solution as a gas and collect in the free volume (water plus gas spaces) in the MCO. The amount of gas in solution at these two temperature conditions can be estimated by applying Henry's law (Perry, 1963).

Table A-2 demonstrates the potential impact of the reduced solubility of air in the water in the $\mathrm{MCO}$ on the pressure measurement as the result of its heatup. The pressure change for an isolated MCO due to air coming out of solution could equal or exceed that due to hydrogen evolution during an eight-hour test interval. Thus, the initial conditions for the reactivity measurement test should attempt to address this uncertainty by venting the gas head volume a few times after reaching and soaking at the $50^{\circ} \mathrm{C}$ temperature plateau. This would likely be accomplished on a previous eight-hour shift prior to the shift that actually conducted the reactivity measurement data collection. It should be noted that the impact of air coming out of solution during the reactivity measurement would add to the measured pressurization and imply a larger than actual reaction area. This could result in a degree of conservatism in the safety assessment which used such an over-estimate of the reactive surface area.

Another impact of the presence of dissolved oxygen is on the reaction rate. The reaction rate used in this assessment assumes that oxygen is present. If the water surrounding the reacting uranium becomes de-oxygenated during the test then the reaction rate would increase per the data cited in the main report (see Figure 1).

The next gas solubility and adsorption effects to be considered regarding test parameter uncertainties should address the possibility of hydrogen produced during the reaction of interest "hiding out" in the MCO being tested. By "hiding out" it is meant that as the hydrogen is evolved by the reaction between water and uranium metal it is stored within the system in a manner that does not change the measured MCO gas head space pressure. Some of the 
Table A-2

Estimate of Impact of Reduced Solubility of Air Due to MCO Heatup

Henry's law states

$$
\begin{aligned}
& \mathrm{H}=\mathrm{p}_{\text {air }} / \mathrm{x}_{\text {air }} \quad \text { (Perry, 1963) } \\
& \mathrm{H}=6.07 \mathrm{E} 4 \text { at } 15^{\circ} \mathrm{C} \text { for air in water } \\
& \mathrm{H}=9.46 \mathrm{E} 4 \text { at } 50^{\circ} \mathrm{C} \text { for air in water }
\end{aligned}
$$

Given that the gas space is air at approximately atmospheric pressure

$$
\begin{aligned}
x_{\text {air }}=\frac{p_{\text {air }}}{H}=\frac{1 \mathrm{~atm}}{H}= & 1.65 \mathrm{E}-5 \frac{\text { mole air }}{\text { mole solution }} \\
\text { at } 15^{\circ} \mathrm{C} & =1.06 \mathrm{E}-5 \frac{\text { mole air }}{\text { mole solution }} \\
& \text { at } 50^{\circ} \mathrm{C}
\end{aligned}
$$

$\therefore \Delta x_{A}=5.9 E-6 \frac{\text { mole air }}{\text { mole solution }}$ is the change in air solubility due to heatup.

The air mass released from solution during heatup is given by

$$
m_{\text {air }} \text { released }=\frac{M W_{\text {air }}}{M W_{\mathrm{H}_{2} \mathrm{O}}} \frac{\Delta x_{\text {air }}}{1-\Delta x_{\text {air }}} m_{\mathrm{H}_{2} \mathrm{O}}
$$

where $M W$ is the molecular weight of each specie $\left(M W_{\text {air }}=28.8 \mathrm{~kg} / \mathrm{kg} \cdot \mathrm{mole}\right.$ and $M W_{\mathrm{H}_{2} \mathrm{O}}=$ $18 \mathrm{~kg} / \mathrm{kg} \cdot$ mole).

The initial volume of water can range between 485 and $815 \ell$ (see Table A-1).

The corresponding range of water mass at $15^{\circ} \mathrm{C}\left(\mathrm{v}=1.0009 \mathrm{~m}^{3} / \mathrm{kg}\right)$ is

$$
\begin{aligned}
& 485 \mathrm{\ell} \times 10^{-3} \frac{\mathrm{m}^{3}}{\ell} \times \frac{1}{1.0009 \mathrm{~m}^{3} / \mathrm{kg}}=0.485 \mathrm{~kg} \\
& 815 \ell \times 10^{-3} \frac{\mathrm{m}^{3}}{\ell} \times \frac{1}{1.0009 \mathrm{~m}^{3} / \mathrm{kg}}=0.815 \mathrm{~kg}
\end{aligned}
$$




\section{Table A-2 - Continued}

The range in the mass of air released during heatup is

$$
\begin{aligned}
m_{\text {air }} \text { released } & =\frac{28.2}{18} \frac{\mathrm{kg} / \mathrm{kg} \cdot \text { mole }}{\mathrm{kg} / \mathrm{kg} \cdot \mathrm{mole}} \frac{6 E-6}{1-6 E-6}(0.485 \mathrm{~kg}) \text { or } \frac{28.2}{18} \frac{\mathrm{kg} / \mathrm{kg} \cdot \mathrm{mole}}{\mathrm{kg} / \mathrm{kg} \cdot \mathrm{mole}} \frac{6 E-6}{1-6 E-6}(0.815 \mathrm{~kg}) \\
& =4.7 E-6 \mathrm{~kg} \text { air or } 7.8 E-6 \mathrm{~kg} \text { air }
\end{aligned}
$$

This corresponds to $1.6 \mathrm{E}-7$ and $2.7 \mathrm{E}-7 \mathrm{~kg}$ mole of air being released.

The initial moles of air in the gas head space and attached piping is estimated from the volume, $33.7 \mathrm{l}$ for atmospheric pressure $\left(10^{5} \mathrm{~Pa}\right)$ and $15^{\circ} \mathrm{C}$ using the ideal gas law

$$
\text { initial } \begin{aligned}
n_{\text {air }} & =\frac{P V}{R T} \frac{\left(10^{5} \mathrm{~Pa}\right)\left(33.7 E-3 \mathrm{~m}^{3}\right)}{\left(8314 \frac{\mathrm{Pa}-\mathrm{m}^{3}}{\mathrm{~K} \mathrm{~kg} \cdot \mathrm{mole}}\right)(288 \mathrm{~K})} \\
& =1.4 E-3 \mathrm{~kg} \cdot \mathrm{mole}
\end{aligned}
$$

If the heatup was done with a constant volume with the $\mathrm{MCO}$ isolated, the measured pressure will increase due to both the heating effect and due to additional moles of gas being added to the fixed gas volume. However, since a negligibly small amount of air comes out of solution the pressure increase is essentially due to only the temperature change.

The ideal gas law can be applied to demonstrate this effect:

$$
\frac{P_{50^{\circ} \mathrm{C}}}{P_{15^{\circ} \mathrm{C}}}=\left(\frac{323 \mathrm{~K}}{288 \mathrm{~K}}\right) \frac{n_{50}}{n_{15}}
$$


HNF-SD-SNF-CN-022, Rev. 0

FAI/97-32 Page $\frac{38}{57}$ of 48

Rev. O Date: $5 / 1 4 \longdiv { 9 7 }$

\section{Table A-2 - Continued}

where

$\mathrm{n}_{15}$ is the initial moles of gas in the head space volume and connected pipe (33.7 $\ell$ of air at $15^{\circ} \mathrm{C}$ )

$\mathrm{n}_{50}$ is the final moles of gas in the combined head space and attached piping after air comes out of solution (1.6E-7 to $2.7 \mathrm{E}-7 \mathrm{~kg}$ mole) and joins the initial gas inventory

$$
\frac{P_{50^{\circ} \mathrm{C}}}{P_{15^{\circ} \mathrm{C}}}=1.12
$$


hydrogen would go into solution until the water inventory is saturated with hydrogen at the $50^{\circ} \mathrm{C}$ test condition. Furthermore, the evolved hydrogen could be adsorbed onto the solid surfaces inside the $\mathrm{MCO}$.

The amount of hydrogen that can be dissolved in the water in the MCO can be estimated by applying Henry's law with the Henry law's constant for hydrogen in water (see Table A-3). The calculation presented in Table A-3 assumes that the hydrogen evolution would be required to saturate the dissolved hydrogen content of the entire available water inventory inside an MCO. If the reactive area was mostly in the scrap basket and that basket was at the top of the MCO, the hydrogen concentration in the MCO could be stratified. However, even less hydrogen would be dissolved in a smaller water mass. Until this saturated condition was reached, little of the evolved hydrogen would escape the water inventory and be added to the gas head volume or become bubbles in the water in the MCO and thus, add to the gas mass and cause the pressure in the MCO to increase.

Data on adsorption of the evolved hydrogen is not available. Thus, this feasibility study does not attempt to calculate the inventory of evolved hydrogen which would "hide out" as an adsorbed layer on the surfaces inside the $\mathrm{MCO}$. However, it is known that as hydrogen is adsorbed onto the exposed solid surfaces inside the MCO an equilibrium condition can be established such that no further adsorption on the solid surfaces occurs. If this condition is established before the reactivity measurements are taken then no additional adsorption would be expected to occur during the measurement. Alternately, if the measurement interval is long enough the effect of adsorption could be saturated during the initial part of the test and thereby eliminated for the majority of the measurement interval.

\section{A.2 PRESSURIZATION RATE ASSESSMENT}

As discussed in Section A.1 and shown by Equation (A-2), the reactivity measurement will collect data on the pressure history for the MCO and use it to directly infer the reactive area. This calculation will assume that the gas volume, gas temperature and temperature dependent reaction rate are known and are constant during the entire test interval which will likely be several hours long. Several of the test parameter uncertainties which could significantly alter or completely mask the measurement of the evolution of the reaction products can be addressed by carefully establishing an appropriate set of initial conditions. Section A.3 discusses these considerations. 
Table A-3

Estimate of Potential Hydrogen Inventory that could Dissolve in MCO Water Inventory

The total number of moles of $\mathrm{H}_{2}$ evolved $\left(n_{H_{2}}\right)$ during the test will be partitioned between the water $\left(n_{H_{2}}^{d}\right)$ and gas $\left(n_{H_{2}}^{g}\right)$ regions in the MCO. Assuming saturated equilibrium a mole balance for hydrogen can be given as

$$
n_{H_{2}}=n_{H_{2}}^{d}+n_{H_{2}}^{g}
$$

Henry's law yields

$$
P_{H_{2}}=H_{H_{2}} x_{H_{2}} \text { with } x_{H_{2}}=\frac{n_{H_{2}}^{d}}{n_{H_{2}}^{d}+n_{H_{2} \mathrm{O}}} \approx \frac{n_{H_{2}}^{d}}{n_{H_{2} \mathrm{O}}}
$$

so

$$
n_{H_{2}}^{d}=\frac{P_{H_{2}} n_{H_{2} O}}{H_{H_{2}}}
$$

The ideal gas law can be applied to the MCO gas space to estimate the partial pressure of $\mathrm{H}_{2}$ as

$$
P_{H_{2}}=\frac{n_{H_{2}}^{g} R T}{V_{g}} \text { where } \mathrm{V}_{\mathrm{g}} \text { is gas head space and attached piping volume. }
$$

or

$$
n_{H_{2}}^{\mathcal{B}}=\frac{P_{H_{2}} V_{g}}{R T}
$$

Direct substitution leads to the expression

$$
n_{H_{2}} \frac{P_{H_{2}} n_{H_{2} \mathrm{O}}}{H_{H_{2}}}+\frac{P_{H_{2}} V_{g}}{R T}=P_{H_{2}}\left(\frac{n_{H_{2} \mathrm{O}}}{H_{H_{2}}}+\frac{V_{8}}{R T}\right)
$$

By assuming some representative numbers for $8 \mathrm{hr}$ test interval at $50^{\circ} \mathrm{C}$ the partial pressure of $\mathrm{H}_{2}$ remaining in the gas region can be estimated. 
Table A-3 - Continued

Consider

$$
\begin{aligned}
& n_{H_{2}}=0.025 \mathrm{~g} \cdot \text { mole } \mathrm{H}_{2} \text { evolved } \\
& \left(\frac{\dot{n}_{H_{2}}}{A}=E-7 \frac{g \cdot \text { mole } H_{2}}{m^{2}-s} \text { and } A=10 \mathrm{~m}^{2} \text {, see Table } A-4\right) \\
& n_{\mathrm{H}_{2} \mathrm{O}}=26.94 \mathrm{~g} \text { mole } \mathrm{H}_{2} \mathrm{O} \\
& \text { (0.485 kg H} \mathrm{H}_{2} \mathrm{O} \text {, see Table 2) } \\
& V_{g}=33.4 \ell \\
& T^{\prime}=323 \mathrm{~K} \\
& \mathrm{H}_{\mathrm{H}_{2}}=7.65 \mathrm{E} 4 \frac{\mathrm{atm}}{\text { mole } \mathrm{H}_{2} / \text { mole } \mathrm{H}_{2} \mathrm{O}} \\
& R=0.08206 \frac{\ell-a t m}{g \cdot \text { mole }-K}
\end{aligned}
$$

Then

$$
\begin{aligned}
0.025 & =P_{H_{2}}\left(\frac{26.94}{7.65 E 4}+\frac{33.4}{(.08206)(323)}\right) \\
0.025 & =P_{H_{2}}(3.5 E-4+1.26)=1.26 P_{H_{2}} \\
P_{H_{2}}= & \frac{0.025}{1.26} \mathrm{~atm}=0.020 \mathrm{~atm} \\
& \text { or } \\
n_{H_{2}}^{g}= & \frac{P_{H_{2}} V_{g}}{R T}=\frac{(0.02)(33.4)}{(0.08206)(323)}=0.025 \mathrm{~g} \cdot \text { mole } H_{2}
\end{aligned}
$$

$\therefore$ Negligibly small amount of hydrogen is dissolved in the water in the MCO. 


$$
\text { HNF-SD-SNF-CN-022, Rev. } 0
$$

FAI/97-32 Page $\frac{42}{5 / 4 / 47}$ of $\frac{48}{47}$
Rev. 0 Date:

The sensitivity of this calculation procedure will now be assessed. This assessment will include a discussion of the instrument ranges and accuracy and sensitivity to both temperature variations and different fuel inventories in an MCO.

Table A-4 summarizes a base case calculation for an MCO with a fuel load (270 E length Mk IV assemblies) and no scrap basket. This table illustrates the calculational procedure including the use of the reactivity rate data and the targeted initial test conditions. As discussed in Table A-4, a rate multiplier of one has been used here. An assumed reactive area of $10 \mathrm{~m}^{2}$ is used. The resulting pressurization rate is shown to be $0.085 \mathrm{~Pa} / \mathrm{sec}$.

The accuracy and range of the pressure and temperature instruments are important considerations in assessing the feasibility of the reactivity measurement. Table A-5 lists the planned instrumentation including the ranges and accuracy of the sensors. The respective manufacturers were contacted to ascertain the accuracy of the selected instrumentation. Two pressure instruments with ranges from 0 to 10 torr and 0 to 1,000 torr are provided. The accuracy of the selected pressure instruments is $\pm 0.5 \%$ of the reading. This combination of instrument ranges and accuracy could provide sufficient resolution to monitor the pressurization which could be produced by the reaction products from the reaction of interest. For example, if a four-hour test interval was assumed and the pressurization rate of 0.085 pascals per second was observed the pressure increase above the initial pressure of 1 atm would be 1224 pascal which could be detected within by the absolute pressure measurement to within $0.5 \%$ or \pm 500 pascals. Such a pressure change is within the range and accuracy of the $0-1000$ torr instrument which is assumed to be an absolute pressure measurement. However, if the four-hour test was conducted and the reaction area was only $1 \mathrm{~m}^{2}$, the pressure change would be approximately 122 pascals. This change is not within the accuracy of the $1-1000$ torr instrument. The test duration would have to be four times longer $(\sim 16 \mathrm{hr})$ to be able to register a pressure change that matched the pressure measurement accuracy. If a four-hour test were conducted and a reaction area was 20 $\mathrm{m}^{2}$ the pressure change would be approximately 2400 pascals which is readily within the range of the $1-1,000$ torr gauge accuracy. These qualitative estimates represent sufficient sensitivity to different potential fuel inventories in the $\mathrm{MCO}$ or different degrees of cladding damage and uranium metal exposure. A smaller fuel inventory in an MCO could lead to a potentially smaller reactive surface area and a correspondingly slower formation of reaction products. This would be reflected in a smaller pressurization rate. A lower bound on the reactive surface area of interest for the safety evaluations could be used to set the required test duration. If the lower 
Table A-4

Base Case Pressurization Estimate

An MCO with a full fuel load ( 270 assemblies) is assumed to be installed in the CVD process skid and its initial conditions set:

$$
\begin{aligned}
& \mathrm{V}_{\mathrm{g}}=33.4 \ell \\
& \mathrm{T}=50^{\circ} \mathrm{C}(323 \mathrm{~K})
\end{aligned}
$$

The temperature dependent reaction per unit area $(\mathrm{k})$ for the $\mathrm{U}-\mathrm{O}_{2}-\mathrm{H}_{2} \mathrm{O}$ system at $323 \mathrm{~K}$ can be calculated from

$$
\log (k)=8.333-\frac{3730}{T} \quad T \text { in } K
$$

However, this expression is based on data for unirradiated uranium. Research indicates that irradiation and surface roughness effects could cause the reaction rate to increase by a factor of 2 to 10. If it is assumed that the shape of the rate law is the same then a simple multiplier (M) can be used to represent these effects

$$
\log \left(\frac{k}{M}\right)=8.333-\frac{3730}{T}
$$

A value of one will be used for $M$ in this assessment. However, this is a major unresolved item which must be addressed before the test interval can be specified.

$$
\begin{aligned}
& \log \left(\frac{k}{1}\right)=8.333-\frac{3730}{323}=-3.215 \\
& k=6.1 E-4 \frac{\mathrm{mg} \mathrm{O}}{\mathrm{cm}^{2} \mathrm{hr}}
\end{aligned}
$$

A convenient reaction rate unit is $g$ mole $\mathrm{H}_{2} / \mathrm{m}^{3}-\mathrm{sec}$ and the appropriate conversion factor $(\mathrm{k})$ is

$$
\frac{1 \mathrm{mg} O}{\mathrm{~cm}^{2} \mathrm{hr}} \times \frac{1 \mathrm{hr}}{3600 \mathrm{~s}} \times \frac{1 \mathrm{~g}}{10^{3} \mathrm{mg}} \times \frac{10^{4} \mathrm{~cm}^{2}}{\mathrm{~m}^{2}} \times \frac{1 \mathrm{~g} \text { mole } \mathrm{O}}{16 \mathrm{~g} O} \times \frac{1 \mathrm{gmale} \mathrm{H}_{2}}{1 \mathrm{~g} \text { mole } \mathrm{O}} \frac{\mathrm{gmole} \mathrm{H}_{2}}{\mathrm{~m}^{2}-\mathrm{s}}=1.736 \mathrm{E}-4
$$

So,

$$
\frac{\dot{n}_{H_{2}}}{A} @ 50^{\circ} \mathrm{C}=1.06 E-7 \frac{g \cdot \text { mole } H_{2}}{m^{2}-s}
$$




\section{Table A-4 - Continued}

The actual exposed surface area of uranium metal is unknown and is the object of conducting the reactivity measurement. However, in this estimate the reactive surface area of $10 \mathrm{~m}^{2}$ is assumed.

Per Equation (A-2) the pressurization rate is

$$
\begin{aligned}
& \dot{P}=\frac{\dot{n}}{A}(T) A \frac{R T}{V} \\
& \dot{p}=1.06 E-7 \frac{g \cdot \text { mole }}{m^{2}-s} 8.314 \frac{P a-m^{3}}{K g \cdot m o l e} \frac{323 \mathrm{~K}}{3.34 E-2 \mathrm{~m}^{3}} \\
& \dot{p}=0.085 \mathrm{~Pa} / \mathrm{s} \text { or } 300 \mathrm{~Pa} / \mathrm{hr}
\end{aligned}
$$

The test duration can be selected to assure that the observed pressure change is sufficient to be accurately measured. 
HNF-SD-SNF-CN-022, Rev. 0

FAl/97-32 Page $\frac{45}{5 / 14 / 97}$
Rev. 0 Date:

Table A-5

Test Instrumentation Ranges and Accuracy

\begin{tabular}{|c|c|c|c|c|c|}
\hline $\begin{array}{l}\text { Component } \\
\text { Description }\end{array}$ & Tag & Manufacturer & $\begin{array}{l}\text { Model } \\
\text { Number }\end{array}$ & Range & Accuracy \\
\hline $\begin{array}{l}\text { Pressure Indicator } \\
\text { and Transmitter }\end{array}$ & $\begin{array}{l}\text { PI- } 1 * 08 \\
\text { PT- } 1 * 08\end{array}$ & $\begin{array}{l}\text { MKS } \\
\text { Instruments } \\
\text { Inc. }\end{array}$ & $\begin{array}{l}\text { 230DA- } \\
\text { 00010BBB }\end{array}$ & $0-10$ torr $^{(1)}$ & $\underset{\text { reading }}{ \pm 0.5 \% \text { of }}$ \\
\hline $\begin{array}{l}\text { Pressure Indicator } \\
\text { and Transmitter }\end{array}$ & $\begin{array}{l}\text { PI- } 1 * 10 \\
\text { PT- } 1 * 10\end{array}$ & $\begin{array}{l}\text { MKS } \\
\text { Instruments } \\
\text { Inc. }\end{array}$ & $\begin{array}{l}\text { 230DA- } \\
\text { 01000BBB }\end{array}$ & $0-1000$ torr $^{(1)}$ & $\begin{array}{l} \pm 0.5 \% \text { of } \\
\text { reading }\end{array}$ \\
\hline $\begin{array}{l}\text { Temperature } \\
\text { Elements }\end{array}$ & $\begin{array}{l}\text { TE- } 1 * 07 \\
\text { TE-2*14 } \\
\text { TE-2*15 } \\
\text { TE-2*18 } \\
\text { TE-3*05 } \\
\text { TE-3*12 } \\
\text { TE-3*13 }\end{array}$ & $\begin{array}{l}\text { MTI Industrial } \\
\text { Sensors }\end{array}$ & $\begin{array}{c}\text { RC-4-9-A" } \\
-D-3-P 10 \\
\text {-H012-TTC } \\
-B 11\end{array}$ & $0-400 \mathrm{~F}$ & $\begin{array}{l} \pm 1 \% \text { full } \\
\text { scale }\end{array}$ \\
\hline
\end{tabular}

(1) Maximum service conditions are 5 psi and $140^{\circ} \mathrm{F}$. Overpressure limit is 35 psia. 
bound reactive surface area were set at $0.3 \mathrm{~m}^{2}$ for example, then the pressure change in four hours would have to be extended to approximately $54^{\prime} \mathrm{hr}$ to detect a pressure change. If the pressure measurements were configured to measure a differential pressure, then the pressure changes for the 1,10 and $20 \mathrm{~m}^{2}$ areas and a four hour test could be adequately detected by a 0 - 1000 torr pressure instrument. A reactive area as small as $0.3 \mathrm{~m}^{2}$ would require a test interval of approximately $8 \mathrm{hr}$ to register a $73 \mathrm{~Pa}(0.5 \mathrm{torr})$ pressure. This would be expected to be observable on a $0-10$ torr differential pressure instrument with limited confidence and probably represents the lower detectable surface area limit.

This evaluation indicates that if the selected pressure instruments are configured as absolute pressure devices than test intervals in excess of several days would be needed to resolve reactive surface areas as small as $0.3 \mathrm{~m}^{2}$. However, if the pressure instruments are configured as differential pressure devices the test interval could be $8 \mathrm{hrs}$ or less.

These observations are based on the calculation provided in Table A-4 which only considers variations in the surface area and resulting pressure change. Variability in the other parameters (gas volume, temperature and reaction rate) remains to be formalized in the final assessment.

The range and accuracy of the specified temperature sensor, will result in resolution to within $\pm 2.2^{\circ} \mathrm{C}$. The sensitivity assessment can be expanded to include temperature variations as presented in Table A- 6 . A range of temperature variation of $\pm 4^{\circ} \mathrm{C}$ about the targeted $50^{\circ} \mathrm{C}$ test condition is evaluated. The evaluation assumes that a pressurization rate of 0.085 pascal per second was measured in each case. Each temperature in the table was used to assess the corresponding reaction rate and then Equation (A-2) was used to calculate the corresponding reactive surface area. The table displays a range in the calculated value for the reactive surface area. If the temperature was thought to have been $50^{\circ} \mathrm{C}$, but due to the accuracy of the temperature measurement was actually $48^{\circ} \mathrm{C}$ then the reactive surface area required to produce a 0.085 pascal per second variation would be $14.2 \mathrm{~m}^{2}$ rather than $10 \mathrm{~m}^{2}$ which would correspond to a system at $50^{\circ} \mathrm{C}$. Thus, the inaccuracy in the temperature measurement could lead to approximately a $20 \%$ discrepancy in the inferred reactive surface area. Furthermore, the temperature of the $\mathrm{MCO}$ could vary during a multiple hour test depending upon the ability of the tempered water system to maintain a constant temperature. If the tempered water system resulted in a bath temperature of $\pm 4^{\circ}$ approximately a $40 \%$ variation in the inferred reactive surface area could result. Thus, it would be important to assure that the tempered water temperature history is monitored and recorded during the test so that any variations during the test interval could be documented and quantified (if required) when the reactive surface area is inferred. 
Table A-6

Sensitivity of Inferred Reactive Surface Area to Temperature Variations

Temperature directly effects the area calculation per the use of the ideal gas law (see Equation (A-2)) and due to the temperature dependence of the reaction rate (see Table A-4 and figure 1). The sensitivity of the inferred reactive surface area is investigated here by assuming that a pressurization rate of $0.085 \mathrm{~Pa} / \mathrm{sec}$ has been measured and calculating the reactive area that would be required for different actual temperatures.

\begin{tabular}{|c|c|c|}
\hline $\begin{array}{c}\text { Actual } \\
\text { Temperature }\end{array}$ & $\begin{array}{l}\text { Reaction }^{(1)} \\
\text { Rate }\end{array}$ & $\begin{array}{l}\text { Reactive } \\
\text { Surface Area }\end{array}$ \\
\hline (K) & $\left(\frac{g \cdot \text { mole } H_{2}}{m^{2}-s}\right)$ & $\left(\mathrm{m}^{2}\right)$ \\
\hline 319 & $7.58 \mathrm{E}-8$ & 14.2 \\
\hline 321 & $8.96 \mathrm{E}-8$ & 11.9 \\
\hline 323 & $1.06 \mathrm{E}-7$ & 10.0 \\
\hline 325 & $1.25 \mathrm{E}-7$ & 8.4 \\
\hline 327 & $1.46 \mathrm{E}-7$ & 7.1 \\
\hline
\end{tabular}

For example, if the indicated temperature was $323 \mathrm{~K}$ but the actual temperature was $321 \mathrm{~K}$ then the inferred reactive surface area would be $10 \mathrm{~m}^{2}$ but the actual surface would be $11.9 \mathrm{~m}^{2}$. 


\section{A.3 MEASUREMENT PROCEDURE CONSIDERATIONS}

The feasibility of the direct reactivity measurement will require the careful establishment of the initial test conditions to accommodate the effects of thermal expansion during the heatup step of the cold vacuum drying process. The following steps should be included in the test procedure that addresses the initial conditions for these measurements.

1. The MCO should be vented during the heatup step to allow escape of any air that comes out of solution from the fuel basin water.

2. Once the $\mathrm{MCO}$ and its contents have been heated to $50^{\circ} \mathrm{C}$ by the tempered water bath, a dwell interval of several hours at $50^{\circ} \mathrm{C}$ should be provided. By soaking at this temperature the objective will be to produce a thermal equilibrium between the $\mathrm{MCO}$ and its contents including the gas and water spaces.

3. The planned gas head volume should be confirmed and reestablished by removing water through the short draw tube. This will correct for the change in water volume during the heatup step and assure that the desired gas space volume is established.

4. The temperature of the MCO should be monitored and recorded during the test interval so any variations in the temperature during the test interval can be quantified when the data is processed and the reactive area is inferred. 
HNF-SD-SNF-CN-022, Rev. 0

ATTACHMENT B 


\section{TELECON}

TIME: 12:45 P.M:

DATE: $6 / 27 / 97$

PLACE MO285, 200E

PARTICIPANTS: R. Hammersely (Fauske \& Associates), DRDuncan (SNF Project)

COMMENTS:

R.Hammersly concurred with the changes by RGCowan to FAl/97-32 which were faxed to him on 6/27/97. 
FAI/97-32 Page 1 of $5^{\circ}$

Rev. 0 Date:

FAI/97-32

FEASIBILITY OF DIRECT REACTIVTTY MEASUREMENT IN MCOS AT THE COLD VACUUM DRYING FACTLITY (CVDF) (Safety Related)

\author{
Submitted to \\ Duke Engineering and Services Hanford SNFP
}

Prepared by

Fauske \& Associates, Inc. 16W070 West 83rd Street Burr Ridge, Mlinois 60521

Phone: 630-323-8750

Fax: $\quad 630-986-5481$

March, 1997 


\section{- 1.0 PURPOSE}

The purpose of this calculation is to assess the feasibility of an integral reaction rate proof test at the Cold Vacuum Drying Facility (CVDF). The purpose of the proof test is to measure the reactivity of uranium fuel in an $\mathrm{MCO}$. These measurements may contribut to the safety basis for the CVDF. The proposed direct reactivity measurement tests will measure the rate of release of hydrogen which is a reaction product for uranium metal corrosion. The hydrogen concentration in a helium purge stream will be measured with a spectrometer. A second reactivity measurement approach based on observing the pressure increase in the head space in the $\mathrm{MCO}$ after the water has been heated to $50^{\circ} \mathrm{C}$ has also been identified and its feasibility assessed (Appendix A). Each test strategy directly measures the $\mathrm{MCO}$ reactivity for the single given test temperature $\left(50^{\circ} \mathrm{C}\right)$. The $\mathrm{MCO}$ reactivity at other temperatures is also needed. This can be estimated by considering the reactivity to be the product of the reaction rate per unit area and the reactive area of the uranium in the given $\mathrm{MCO}$. The available temperature dependent reaction rate data can be used to infer the MCO's reactive area for the $50^{\circ} \mathrm{C}$ measurement temperature. The inferred reactive area is not temperature dependent. It can be used to estimate the $\mathrm{MCO}$ reactivity at other temperatures when the available reaction rate data is applied to those other MCO conditions. Measurement inaccuracies and their impact on the feasibility of these measurements are determined.

This feasibility assessment will be based upon the planned facility configuration and instrumentation as currently defined (DRAFT 90\%). The feasibility assessment will also consider the ability to perform the direct reactivity measurements in a reasonable time interval. A period of a shift (approximately 8 hours) or less has been assumed as a reasonable time interval objective. 


\section{$\therefore \quad 2.0$ SUMMARY AND CONCLUSIONS}

It is concluded that the proposed reactivity measurement based on recording the changes in the molar ratio of hydrogen to helium in the purge flow due to the reaction products from the uranium metal water reaction is feasible. The currently planned CVDF design may require some modification for spectrometer sample line. A reasonable, i.e., less than one șhift, test duration can likely be used and still assure sufficient accuracy for confidence in the measurement results.

The major conclusions from this feasibility study are

- measurement strategy is feasible given that a means is added to the facility (new equipment) for / removing water vapor from the MCO gas sample supplied to the mass spectrometer desired MCO pressure ( 100 torr) )

- the actual rate law for spent fuel must be confirmed so that the specific test parameters (helium purge rate and test interval) can be established. 
The reaction rate data per unit area of uranium for the $\mathrm{U}-\mathrm{H}_{2} \mathrm{O}$ system for spent fuel is needed to estimate the reactive area of the exposed and unreacted uranium surface in the MCO. It should be recognized that the amount of fuel and its shape and exposed uranium surface area will vary for each MCO such that a specific measurement will be needed for each MCO to ascertain the appropriate uranium surface area for it. This surface area can then be used in calculations and assessments that

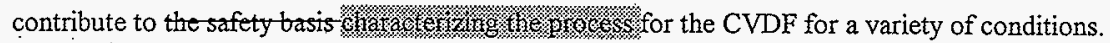

The key consideration for determining the feasibility of the direct integral reactivity measurement is to ascertain the ability to establish the proper set of initial conditions that would allow the direct application and interpretation of Equation (1). A practical issue for these measurements is the time required to obtain stable data for each $\mathrm{MCO}$.

The helium purge method has been selected over the MCO head space pressurization reactivity method of reactivity measurement based on this practical consideration. The estimated time for the pressurization measurement could be as long as $8 \mathrm{hr}$ (see Appendix A) to assure sufficient accuracy given the possible uncertainties. The estimated time for the helium purge method is approximately an hour given a well behaved reaction rate characterization. Thus, the two measurement techniques appear to be feasible but the helium purge method appears to provide the most practical approach.

The test parameters and initial conditions which may influence the helium purge direct integral reactivity measurement are screened below to determine their effects and identify suitable means of addressing them.

\section{1:1 Thermal Effects}

The MCO is filled with spent fuel and fuel basin water when it is delivered to the CVDF for processing. Thus, it is initially at ambient conditions which are assumed to be approximately $15^{\circ} \mathrm{C}$. The tempered water system is used to heat the transfer cask, $\mathrm{MCO}$ and the $\mathrm{MCO}$ contents to $50^{\circ} \mathrm{C}$ over an approximate duration of 300 minutes. (see CVDF process flow diagram, H-1-82166.) Any decay heat or exothermic reaction heat liberated during the heating process will simply assist the heatup step by the tempered water system. Once the $\mathrm{MCO}$ and transfer cask are heated to $50^{\circ} \mathrm{C}$ it is assumed in this assessment that the tempered water system will maintain them at a uniform $50^{\circ} \mathrm{C}$. It is further assumed that a thermal equilibrium will be established and maintained by the tempered water system between the MCO contents (fuel, water and gas space). 
-. Table 1 summarizes a base case calculation. This table illustrates the calculational procedure including the use of the reactivity rate data and the targeted initial test conditions. As discussed in Table 1, a rate multiplier of one has been used here. An assumed reactive area of $10 \mathrm{~m}^{2}$ is used. The resulting molar ratio of hydrogen to helium for a $10 \mathrm{~m}^{2}$ reactive area is shown to be 0.4 which is well within the resolution possible with the mass spectrometer. Table 2 indicates a detection limit of 50 ppm: Given 100 ppm hydrogen in helium the molar ratio is very small, i.e., $2 \mathrm{E}-4$ which means that the spectrometer could detect very low hydrogen concentrations. Also, a reactive area of only 0.5 $\mathrm{m}^{2}$ would result in a molar ratio of 0.008 which is also within the possible resolution.

The accuracy and range of the pressure, temperature, purge flow and spectrometry instruments are important considerations in assessing the feasibility of the reactivity measurement. Table 2 lists the planned instrumentation including the ranges and accuracy of the sensors. The respective manufacturers were contacted to ascertain the accuracy of the selected instrumentation. Two pressure instruments with ranges from 0 to 10 torr and 0 to 1,000 torr are provided. The accuracy of the selected pressure instruments is $\pm 0.5 \%$ of the reading. This combination of instrument ranges and accuracy could provide sufficient resolution to monitor the hydrogen which could be produced by the reaction products from the reaction of interest.

An assessment of the impact of instrument errors and accuracy is provided here. The MCO pressure will be controlled during its heat-up to $50^{\circ} \mathrm{C}$ by the tempered water and vacuum systems. The desired pressure which corresponds to the saturation condition at $50^{\circ} \mathrm{C}$ is $12.35 \mathrm{~K} \mathrm{~Pa}$ (95 torr). The accuracy of the $0-1000$ torr pressure instrument is $\pm 0.5 \%$ of the reading or $\pm 0.06 \mathrm{~K} \mathrm{~Pa}$ ( 646 torr).

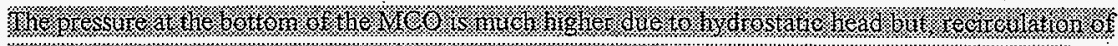

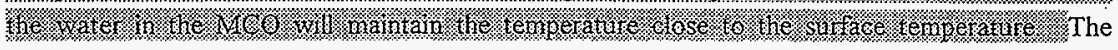
corresponding range in the system temperature due to this range of variation in the pressure measurement is $\pm 0.1^{\circ} \mathrm{C}$. The combined impact on the inferred reaction area of the inaccuracies in the pressure measurement and concomitant variation in the corresponding saturated water temperature is small ( $\pm 0.6 \%$ variation in $k$ as shown in Table 3 ). This variation is smaller than the data scatter used to derive the reaction rate correlation. Table 3 also assess the potential impact for variation from thermal equilibrium at $50^{\circ} \mathrm{C}$ and its impact on the reaction rate. This impact on the accuracy of the reactivity measurement is discussed below. 


\section{DISTRIBUTION SHEET}

\begin{tabular}{|c|c|c|c|c|c|}
\hline \multirow{2}{*}{$\begin{array}{l}\text { To } \\
\text { Distribution }\end{array}$} & \multirow{2}{*}{\multicolumn{3}{|c|}{$\begin{array}{l}\text { From } \\
\text { Process Engineering }\end{array}$}} & \multicolumn{2}{|l|}{ Page 1 of 1} \\
\hline & & & & \multicolumn{2}{|c|}{ Date August 27,1997} \\
\hline \multirow{2}{*}{\multicolumn{4}{|c|}{$\begin{array}{l}\text { Project Title/Work Order } \\
\text { Feasibility of Direct Reactivity Measurement in Multi-Canister } \\
\text { Overpacks at the Cold Vacuum Drying Facility }\end{array}$}} & \multicolumn{2}{|c|}{ EDT No. 616163} \\
\hline & & & & \multicolumn{2}{|c|}{ ECN No. N/A } \\
\hline Name & MSIN & $\begin{array}{l}\text { Text } \\
\text { With All } \\
\text { Attach. }\end{array}$ & Text Only & $\begin{array}{l}\text { Attach./ } \\
\text { Appendix } \\
\text { Only }\end{array}$ & $\begin{array}{l}\text { EDT/ECN } \\
\text { Only }\end{array}$ \\
\hline
\end{tabular}

Duke Engineering \& Services Hanford
D. W. Bergmann
R. G. Cowan (5)
D. R. Duncan
J. R. Frederickson
L. H. Goldmann
R. P. Omberg
R. W. Rasmussen
K. E. Smith
J. A. Swenson
$\times 3-79$
$\mathrm{R} 3-86$
R3-86
R3-86
R3-86
R3-15
R3-86
R3-86
R3-11
$\mathrm{R} 3-85$
C. A. Thompson
X3-85

$x$
$x$
$x$
$x$
$x$
$x$
$x$
$x$
$x$
$x$
M. J. Wiemers

$\times 3-85$

R3-11

$x$

E. W. Gerber

K9-46

R3-86

R3-86

$X$
$X$
$X$

C. R. Miska

SGN Eurisys Services Corporation

E. A. Nelson

A. L. Pajunen

R3-85

R3-86

$X$
$X$

SNF Project Files

Central Files

R3-11

A3-88

$X$
$X$ 